\title{
Çocuk katılımı farkındalık ölçeği (ÇKFÖ): Ölçek geliştirme, güvenirlik ve geçerlik çalışması
}

\author{
Child participation awareness scale (CPAS): Scale development, reliability \\ and validity study
}

\author{
Berrak Deniz Polat ${ }^{1}$, Özlem Alkan Ersoy ${ }^{2}$, Mehmet Toran ${ }^{3}$
}

\begin{abstract}
Öz: Bu çalışmanın amacı, çocuk gelişimi ve okul öncesi öğretmenliği bölümünde okuyan öğrencilerin çocuk hakları bağlamında katılım hakkı ile ilgili görüşlerini belirlemeye yönelik bir ölçek geliştirmektir. İlk olarak literatür taranarak oluşturulan 98 maddelik ölçme aracı alanında uzman 7 kişiye gönderilmiştir. Yorum ve görüşleri doğrultusunda ölçeğe 43 madde değiştirilmeden olduğu gibi geçmiş, 2 madde eklenmiş, 10 madde öneriler doğrultusunda düzenlenmiş, maddeler yakınlık derecesine göre sıralanmış ve 55 maddelik 5'li likert tipi bir ölçek ön formu oluşturulmuştur. 55 maddeden oluşan taslak ölçek 2016-2017 eğitim öğretim yılı bahar döneminde İstanbul ilinde bulunan iki vakıf üniversitesindeki çocuk gelişimi ve okul öncesi öğretmenliği bölümlerinde okuyan toplam 481 gönüllü öğrenciye uygulanmıştır. Ölçek geliştirme sürecinde açımlayıcı faktör analizi, doğrulayıcı faktör analizi, güvenirlik analizleri, test-tekrar test gibi çeşitli analizler yapılmıştır. Bu analizler sonucunda 18 madde ve 5 alt ölçekten oluşan Çocuk Katılımı Farkındalık Ölçeği; çocuk gelişimi ve okul öncesi öğretmenliği öğrencilerinin çocuk hakları bağlamında katılım hakkı ile ilgili görüşlerini belirlemede geçerli ve güvenilir olduğunu kanıtlar niteliktedir.
\end{abstract}

Anahtar Kelimeler: Çocuk hakları, katılım hakkı, ölçek geliştirme

\begin{abstract}
The purpose of this study is to develop a scale for the purpose of determining the views of students in the Child Development and Preschool Teaching Department regarding the right to participate in the context of children's rights. Firstly, 98-article measurement tool which created by scanning the literature was sent to 7 experts. In the light of comments and opinions, 43 articles were passed on the scale, 2 articles added, 10 articles are arranged in line with the suggestions, the articles are ranked according to their degree of similarity and a 5-point 55 article likert-type scale pre-form was created. The draft scale consisting of 55 articles was applied to total of 481 volunteer students of departments of Child Development and Preschool Teaching at two foundation universities in Istanbul during 2016-2017 academic year spring term. In the scale development process, various analyses such as exploratory factor analysis, confirmatory factor analysis, reliability analysis, test-retest were conducted. As a result of these various analyses applied in the scale development process, the Child Participation Awareness Scale consisting of 18 articles and 5 subscales proves that; the scale is valid and reliable in determining the opinions departments of Child Development and Preschool Teacher students regarding the right to participate in the context of children's rights.
\end{abstract}

Keywords: Children's rights, right for participation, scale development

\footnotetext{
${ }^{1}$ İstanbul Arel Üniversitesi, MYO, Çocuk Gelişimi Programı, bdenizp@gmail.com

${ }^{2}$ Gazi Üniversitesi, Eğitim Fakültesi, Temel Eğitim Bölümü, Okul Öncesi Eğitimi ABD, ozlemerso@gmail.com

${ }^{3}$ İstanbul Kültür Üniversitesi, Eğitim Fakültesi, Temel Eğitim Bölümü, Okul Öncesi Eğitimi ABD, m.toran@iku.edu.tr
} 


\section{SUMMARY}

\section{Introduction}

Children's rights in a universal notion which covers the physical, psychological, sociological and political rights of all children on the world they have as of their birth pursuant to the principles accepted by the society and the laws, meaning within the frame of positive and natural law (Wald, 1987; Merey, 2016). The most accepted and the children's rights regulating legal text in law in international sense is the on $20^{\text {th }}$ November 1989 unanimously accepted United Nations Convention on the Rights of the Child (UNCRC) (Akyüz, 2015). The articles of the convention are integral and all articles are associated with each other (Hodgkin \& Newell, 2003, s. 164). The convention groups the children's rights under four main headings, being the right to live, the right to develop, the right on protection and the participation right (Akyüz, 2015). The convention has introduced an approach, which was never mentioned before with regards to human rights. Neither is in the Universal Declaration of Human Rights of 1948 nor in the Declaration on the Rights of the Child of 1959 talked about the participation right of the child (Flowers, 2010). Participation is the development of the power and capacities to participate to decisions and actions that might be influential on themselves (UNICEF, 2009). Article 12 of the UNCRC is the most basic article related to the participation right; it states that the children have a right to declare their opinion against any situation related to them in accordance with their age and development and that the undersigned countries need to provide participation opportunities on this issue for children and to take their participation serious. An efficient and meaningful participation depends on many factors like the developing skills of the child, the openness of the families and other adults towards the participation of the child and the presence of safe environments in the family, society and public. Beside this, also the existence of stakeholders willing to pay regard to the opinions of the child is extremely important (UNICEF, 2009). The satisfactory provision of participation rights to children depends on the provision of suitable, correct information according to the age and development of the child and that they are informed, the creation of possibilities for all initiatives of the children and that the child and its family is not discriminated due to any of its features (Polat \& Şahin, 2012). The general comment of the United Nation's Committee on the Rights of the Child (CRC) published in 2009 related to the "participation right of the child" emphasizes that the notion of participation, the inclusion of the child into processes shouldn't be just a for show participation for that moment, that the right to speak of the children among themselves and adults should always be regarded and supported and that there are some policies, programs and measures need to be taken on this issue. The features need to be given at all processes, where the child or children are listened to, express their opinion and participate to are indicated by the CRC (2009) under the headings that the party is transparent and elucidative, voluntary, respectful, interested, child friendly, inclusionary, education supported, secure and risk sensitive and accountable.

Erken Cocukluk Çalıșmaları Dergisi

Cilt $1 \cdot$ Say1 $2 \cdot$ Ekim
Journal of Early Childhood Studies

Volume 1 - Issue 2 - October 
Beside this, this right shouldn't be deemed as an award or grace against the children, and it should be known that it is a legal, moral and social necessity. Children's rights awareness trainings should be planned and implemented for those working with children or coming somehow in contact with them, meaning for the whole society; it is necessary to communicate that the participation right of the child is an obligation by utilizing children's right related publicity campaigns, social communication advertisements and whole mass communication tools (Polat \& Şahin, 2012).

\section{Method}

The aim of the stud is to develop a Child Participation Awareness Scale (CPAS) in order to determine the opinions of the students with regards to the participation right in the context of children's rights. The working group of the study is constituted by 481 students of the Department of Child Development and Early Childhood Education of two foundation universities in Istanbul, determined in 2017 by the random sampling method. The measurement tool with 98 articles, established as a result of the literature scan and developed in order to determine the opinions students of the department of child development and early childhood education with regards to the participation right in the context of children's rights, is sent to 7 experts in their field and 43 articles are taken into the scale as they are pursuant to their comments and opinions, 2 articles, not present in the sent form, are added to in accordance with the experts' suggestions, the 10 are revised in accordance with the experts' suggestions and the determined articles are ordered according to their closeness level with regards to their meaningfulness and 5-Likert type scale pre-form with 55 articles is established pursuant to the suggestions.

\section{Result}

At the converted basic components' analysis performed for the factorability in the study is the KMO (Kaiser-Mayer-Olkin) value determined to be .78, and the result of the Barlett's test as 2597.798, and 18 variables, included into the analysis, are grouped under 5 factors with an eigenvalue above 1 . The declared total variance quantity of these 5 factors is determined to be $64.515 \%$, and the factor loads vary between .569-.876. The factors are named decoration in child's participation, respect for child participation opinion, restrain child's participation, equality in child participation and physiological needs in child's participation respectively. The internal consistency coefficient of the whole scale is calculated as $\alpha: .80$. The fact that the coefficient $\alpha$ value is greater than .70 indicates that the scale is internally consistent (Nunnally, 1978; Tavşanc1l, 2014, p. 29). According to the analysis results, performed in order to determine the distinctiveness related to the scale sub-dimension and total scores are the sub-dimension and total scores distinctive and they revealed that the variations for all groups are statistically meaningful $(t=39,813 ; \mathrm{p}<.03)$. According to the results of the item total correlation analysis, expected to be greater than .20 (Yalın Sapmaz, et al, 2016, p. 120), are the item

Erken Çocukluk Çalıșmaları Dergisi

Cilt $1 \cdot$ Sayı $2 \cdot$ Ekim
Journal of Early Childhood Studies

Volume $1 \cdot$ Issue $2 \cdot$ October 
total correlation coefficients varying between .24 and .70 , and the item residual correlation coefficients between .20 and .61 and are statistically meaningful. It is seen, according to the Pearson Moment Multiplication Correlation Analysis performed in order to determine the relation between the factors, that there is a meaningful relation in positive direction between all factors and it is concluded that all factors are correlated with each other. Confirmatory Factor Analysis (CFA) was conducted to examine the construct validity of the Child Participation Awareness Scale. For normality, total scores were taken from the scale articles, Kolmogorov-Smirnov test was performed, and skewness values were examined. Kolmogorov-Smirnov test was performed and the skewness values were examined. According to Kolmogorov-Smirnov test results, the scale shows a normal distribution $(p>.05)$. The result shows that CFA resultant $t$ is significant at .05 level above 1.96 and .01 at 2.56 level. According to $T$ values, all articles except article 11 are meaningful at .01 level. The t value of the 11th article is 1.94, just below the critical value of 1.96. These latent variables show that they correctly explain the observed variables. When the standardized solution values were examined, the error variances of all articles except article 8 were evaluated as small, values ranging from .41 to .92 . When we look at the values of adjustment to the results of the Child Participation Awareness Scale, the RMSEA shows a perfect fit. SRMR, AGFI, CFI show good agreement. GFI, NFI and NNFI seem to be well below well-matched. Finally, the total correlation factor is determined to be $(\mathrm{r}=.864 ; \mathrm{p}<.05)$ in the result of the Pearson Moments Multiplication Correlation and dependent groups t-test, performed in order to verify the reliability of the test, and based on this result, it can be stated that the scale is consistent and stable after different applications without changing against time.

\section{Conclusion and Discussion}

It is by the end of all analysis seen that the Child Participation Awareness Scale is a valid and reliable usable measurement tool at determining the opinions students of the department of child development and early childhood education with regards to the participation right in the context of children's rights. There is no scale study regarding the measurement of the attitudes related to the children's participation right in Turkey, and it is thought that the developed Child Participation Awareness Scale might eliminate this deficit and contribute to the literature. Beside this, that the children are aware of their rights, adapt their rights to their lives knowingly and live accordingly is important and necessary according to both the Convention and the Committee on the Rights of the Child. In this direction play the opinions and implementations of early childhood education students, who can directly influence children, an important role. The developed scale can be applied everybody somehow in contact with children, not only the students in this field, and, after having determined the deficiencies, works to eliminate them can be planned.

Erken Çocukluk Çalıșmaları Dergisi

Cilt $1 \cdot$ Say1 $2 \cdot$ Ekim
Journal of Early Childhood Studies

Volume $1 \cdot$ Issue $2 \cdot$ October 


\section{GİRIS}

Çocuk hakları toplum tarafından kabul edilmiş ilkelere ve yasaya uygun olarak, pozitif ve doğal hukuk çerçevesinde dünya üzerindeki bütün çocukların doğuştan sahip olduğu fiziksel, psikolojik, sosyolojik ve politik hakları içinde barındıran evrensel bir kavram olarak kabul edilmektedir (Wald, 1987; Merey, 2016). Çocuk hakları kavramının ortaya çıkışından günümüze kadar olan süreçteki tarihsel gelişimi gerek dünya gerekse Türkiye ölçeğinde incelendiğinde 1924 Cenevre Çocuk Hakları Bildirgesi, 1959 Birleşmiş Milletler Çocuk Hakları Bildirgesi, 1963 Türk Çocuk Hakları Bildirisi ve 1989 Birleşmiş Milletler Çocuk Hakları Sözleşmesi gibi bir sürecin yaşandığı görülmektedir (Erbay, 2013). Uluslararası anlamda hukukta en fazla kabul görmüş ve çocuk haklarını düzenleyen yasal metin 20 Kasım 1989 tarihlinde oy birliği ile kabul edilen Birleşmiş Milletler (BM) Çocuk Haklarına Dair Sözleşme'dir (ÇHS) (Akyüz, 2015). 28 Ocak 1990'da imzaya açılarak 61 ülke tarafından aynı gün imzalan (Koran, 2012) sözleşmenin tüm maddeleri bir bütün içinde ve birbiri ile ilişkili bir şekilde tasarlanmıştır (Hodgkin ve Newell, 2003). Sözleşme çocuk haklarını, yaşama hakları, gelişme hakları, korunma hakları ve katılım hakları olarak dört ana başlıkta gruplandırmaktadır (Akyüz, 2015).

Çocuk Haklarına Dair Sözleşmede, insan hakları açısından da değerlendirildiğinde daha önce hiç bahsedilmemiş olan çocuk katılımı ile yeni bir yaklaşım benimsenmiştir. Evrensel haklara ilişkin yayımlanmış olan önemli sözleşmelerden gerek 1948 İnsan Hakları Evrensel Beyannamesi gerekse 1959 Çocuk Hakları Bildirgesinde çocukların katılım hakkından bahsedilmektedir (Flowers, 2010). Bugüne kadar yapılmış düzenlemelerden farklı olarak, 1989 Çocuk Haklarına Dair Sözleşme çocukların katılım haklarını tanımlayarak ve çocuklara kendilerini ilgilendiren her türlü durumda kendi kararlarını verebilme ve bu sayede kişiliklerini geliştirebilme, toplumsal her durumda kendilerini yaş ve gelişim düzeylerine göre ifade edebilme haklarını tanımlamıştır (Moroğlu, 2003).

Katılım, toplum yararının bir parçası olarak, kişilerin karar alma süreçlerinde ve etkinliklerinde aktif olarak yer alması, bu süreçlerde, karar mercileri, uygulama ve değerlendirme süreçlerine etkin olarak karışması olarak kabul edilmektedir (Talay, Aslan ve Belkayalı, 2010). Katılım çocukların kendileri üzerinde etkili olabilecek kararlar ve eylemlerde yer alma güç ve kapasitelerinin geliştirilmesidir (UNICEF, 2009). Katılım hakları, çocuğun bulunduğu her yerde (aile-toplum) etkin kararlar almasını, uygulamasını, değerlendirmesini sağlamaya 
yönelik haklardır. Bu haklar, ÇHS madde 12 “Çocuğun görüşü, kararlara katılma”; madde 13 “Ifade özgürlüğ̈̈"; madde 14 “Düşünce, din ve vicdan özgürlüğü”; madde 15 "Dernek kurma ve barlş içinde toplanma" hakkıdır (Akyüz, 2015). Kendi görüşlerini oluşturma yeteneğine sahip çocuğa, kendisini ilgilendiren, etkileyen her türlü duruma karşı özgürce ifade ve çocuğun görüşlerine yaşına ve olgunluğuna uygun olarak gereken önem ve özenin gösterilmesi beklenmektedir (Birleşmiş Milletler Çocuk Hakları Komitesi, 2009).

ÇHS madde 12, katılım hakkı ile ilgili en temel maddedir; çocukların kendilerini ilgilendiren her duruma karşı yaş ve gelişimleri doğrultusunda görüş bildirme hakkına sahip olduğunu ve taraf devletlerin çocuklara bu konuda katılım firsatları sağlamasını ve katılımlarını ciddiye alması gerektiğinden bahseder.

ÇHS Madde 12: (1) Taraf devletler, görüşlerini oluşturma yeteneğine sahip çocuğun kendini ilgilendiren her konuda görüşlerini serbestçe ifade etme hakkını bu görüşlere çocuğun yaşı ve olgunluk derecesine uygun olarak, gereken özen gösterilmek suretiyle tanırlar. (2) Bu amaçla, çocuğu etkileyen herhangi bir adli veya idari kovuşturmada çocuğun ya doğrudan doğruya veya bir temsilci ya da uygun bir makam yoluyla dinlenilmesi firsatı, ulusal yasanın usule ilişkin kurallarına uygun olarak çocuğa, özellikle sağlanacaktır (UNICEF, 2004).

Taraf devletler "Kendi görüşlerini oluşturma yeteneğine sahip" her çocuğun katılım hakkının sağlamasını bir sınırlama olarak değil, mümkün olduğu ölçüde çocuğun kendine ait bir görüş oluşturma kapasitesini değerlendirmeleri için bir sorumluluk kabul etmelidir (Birleşmiş Milletler Çocuk Hakları Komitesi, 2009). ÇHS madde 12, çocukların görüşlerini istedikleri ölçüde ifade etmelerine karşın bir alt sınır getirmemekte, çocukların küçük yaşlarda görüş oluşturabileceklerini ve oluşturduklarını belirtmektedir. Dolayısıyla Sözleşme çocukların görüş bildirebileceklerini ve her çocuğun görüşünün dikkate alınması gerektiğini belirterek, "Belirli yaştaki çocukların görüşleri dikkate alınmalıdır." gibi bir alt yaş sınırı getirilmesine tamamen karşıdır (Hodgkin ve Newell, 2003). Ancak çocuk bu hakkı kullanmama hakkına sahiptir. Görüşlerini ifade etmek çocuk için bir yükümlülük değil, bir tercihtir. Fakat taraf devletler çocuğun kendi yararına bir karar verebilmesi için tüm bilgileri ve tavsiyeleri çocuğa uygun ve anlaşılır olarak sunması gerekmektedir (Birleşmiş Milletler Çocuk Hakları Komitesi, 2009). Çocukların katılımları ile ilgili en önemli ilke zekânın her bireyde değişik alanlarda ve değişik oranlarda geliştiğidir (Hart, 2016). Evrensel bir zekâ anlayışından bahsetmektense, her bireyin doğuştan gelen kapasitesi ve bu kapasiteyi kullanabilmesi için sahip olduğu firsatlara göre farklı oranlarda geliştirdiği çok yönlülüğü göz önüne alınmalıdır (Hart, 1978; Hart, 2016). Etkili ve

Erken Çocukluk Çalıșmaları Dergisi

Cilt $1 \cdot$ Say1 $2 \cdot$ Ekim
Journal of Early Childhood Studies

Volume $1 \cdot$ Issue $2 \cdot$ October 
anlamlı katılım, çocuğun gelişen yetenekleri, ailelerin ve diğer yetişkinlerin çocukların katılımına açıklığı ve ailede, toplulukta ve toplumda böyle bir açıklık için güvenli ortamların bulunması gibi birçok etmene bağlıdır. Ayrıca çocukların görüşlerini dikkate almaya istekli paydaşların varlığı da bu noktada son derece önemlidir (UNICEF, 2009).

Aileleri, toplulukları, yetişkinleri ve kurumları çocuk katılımına alıştırmak, önemini anlamalarını sağlamak çok kolay olmamaktadır (Erbay, 2013). Hart (2016) çocuk haklarına karşı ailenin ve yetişkinlerin direnç göstermesini otoritelerini ve çocukları üzerindeki kontrollerini yitirme korkularından olduğunu belirtmektedir. Bir başka görüşe göre de çocuk haklarının büyük ölçüde ihmal edilmesinin nedenlerinde biri insanların meseleyi ciddiye almayışları ve ciddiyetle yaklaşmalarını sağlama güçlügüdür (Franklin, 1993). Oysa aile çocukların öğrenimleri için temel kurumdur ki çocuklar burada; katılım süreçleriyle ilgili ilk deneyimlerini, anlaşmanın temel ilkelerini ve ev içi karar verme edimlerini kazanabilirler. Katılım becerilerini aile içinde geliştirebilirler. Ebeveynlerini, erkek ya da kız kardeşlerini rol model alabilirler (Alderson ve Morrow, 2004; Adhikari, 2016).

Hart (1992) çocukların katılım boyutlarını basamaklandırarak bir katılım merdiveninden bahsetmektedir. Merdiven sekiz basamaktan oluşmakta ilk üç basamak katılım karşıtı olan, manipülasyon, dekorasyon ve göstermelik-sembolik katılım basamaklarıdır. Bu basamaklarda çocuk katılımından bahsetmek imkânsızdır. Katılımın olduğu basamaklar dördüncü basamaktan başlamakta ve katılım düzeyine göre devam etmektedir. Bu basamaklar sırasıyla, çocukların görev ve bilgilendirildiği dördüncü basamak, çocuklara danışılan ve bilgilendirilen beşinci basamak, yetişkinlerin başlattığı kararların ortak alındığı altıncı basamak, çocukların başlattığı ve yönettiği yedinci basamak ve çocukların başlattığı yetişkinlerle paylaşılan sekizinci basamaktır. Birleşmiş Milletler Çocuk Hakları Komitesi’nin 2009 yılında yayınladığı "Çocuğun katılım hakkı" ile ilgili genel yorumunda da katılım kavramının, çocukların süreçlere dahil edilmesinin sadece o ana mahsus göstermelik bir katılım olmamasına, çocukların kendileri ve yetişkinler arasında söz hakkının hep gözetilmesine, desteklenmesine ve bu konuyla ilgili bir takım politikalar, programlar ve önlemler alınması gerektiğine vurgu yapılmaktadır (Birleşmiş Milletler Çocuk Hakları Komitesi, 2009).

Çocukların katılım haklarının etkin bir şekilde gerçekleştirilebilmesi için, çocukların yaşlarına ve gelişimlerine uygun doğru bilgi sunulmasına, bilgi sahibi olmalarına, çocukların tüm girişimleri için olanaklar yaratılmasına ve çocuğun ve ailesinin hiçbir özelliğinden dolayı 
ayrımcılığa uğramamasına bağlıdır (Polat ve Şahin, 2012). Hodgkin ve Newell (2003) katılım haklarının uygulanmasına yönelik stratejiler belirlemiş ve bu stratejileri altı başlıkta toplamışlardır:

1. Bilgi edinme hakkı katılımın ön koşulu.

2. Uygulamanın izlenmesi.

3. Ayrımcılık olmadan katılım hakları.

4. Uygulama, kaynakların yeterliliğine bağlanamaz.

5. Katılım haklarının ulusal yasalarda yer alması.

6. Çocukların katılımını sağlamaya yönelik öğrenim, eğitim ve diğer stratejiler.

Çocuk veya çocukların dinlendiği, görüş bildirdiği ve katıldığı tüm süreçlerde bulunması gereken nitelikler Birleşmiş Milletler Çocuk Hakları Komitesi (BM ÇHK) (2009) tarafından ise şeffaf ve bilgilendirici, gönüllü, saygılı, ilgili, çocuk dostu, kapsayıc1, eğitim ile desteklenmiş, emniyetli ve riske karşı duyarlı ve hesap verebilir başlıkları altında belirtilmiştir. Ayrıca bu hakkın çocuklara verilen bir ödül ya da lütuf gibi görülmemesi, yasal, ahlaksal ve toplumsal olarak gereklilik olduğunun bilinmesi gerekmektedir.

Çocuklarla çalışan ya da bir şekilde karşılaşan yani tüm toplum için çocuk hakları farkındalık eğitimleri planlanmalı ve uygulanmalıdır. Çocuk hakları ile ilgili tanıtım kampanyaları, sosyal iletişim reklamları ve tüm kitle iletişim olanakları kullanılarak çocukların katılım hakkının bir zorunluluk olduğunun anlatılması gerekmektedir (Polat ve Şahin, 2012). Bu bağlamda çocuklarla çalışan profesyonellerin çocuk katılımını etkili bir şekilde gerçekleştirmeleri, bu konuda uygulamaya yönelik eğitim almaları önemlidir. Çocukla çalışan profesyonellerin çocuk katılımına yönelik farkındalıklarının değerlendirilmesi ve değerlendirme sonucunda yeterliliklerinin arttırılmasına yönelik çalışmaların yapılması önem taşımaktadır. Bu noktada çocuk katılımına yönelik değerlendirme araçlarının geliştirilmesi, bu araçların profesyonellerin farkındalıklarını ölçmesi, geliştirilecek uygulamaların etkili bir şekilde uygulanmasında önemli bir role sahip olacaktır. Dolayısıyla mevcut araştırmada çocukla çalışacak profesyonellerden olan çocuk gelişimi ve okul öncesi öğretmenliği bölümü öğrencilerinin çocuk hakları bağlamında katılım hakkı ile ilgili görüşlerini belirlemek amacıyla Çocuk Katılımı Farkındalık Ölçeği (ÇKFÖ) geliştirmektir.

\section{YÖNTEM}

Çocuk Katılımı Farkındalık Ölçeği'nin geliştirilme çalışmasının hangi aşamalarda gerçekleştiği ve çalışma grubuna ilişkin özellikler bu bölümde verilmiştir. Çocuk Katılımı Farkındalık Ölçeği 
çocuk hakları bağlamında çocuk katılımı ile ilgili görüşlerin istatistiksel olarak açıklanmasını sağlayacaktır. Bu çalışmada Çocuk Katılımı Farkındalık Ölçeği'ni geliştirmek için gerekli geçerlik ve güvenirlik çalışmaları yapılmıştır.

\section{Çalışma Grubu}

Araştırmanın çalışma grubunu 2017 yılı İstanbul ilinde bulunan iki vakıf üniversitesinden gelişi güzel örnekleme yöntemi ile belirlenmiş Çocuk Gelişimi (289) ve Okul Öncesi Öğretmenliği (192) Bölümü öğrencilerinden 481 kişi oluşturmaktadır. Bu tür örnekleme araştırmacının saptanan örneklem büyüklüğüne göre herhangi bir şekilde evrenin bir parçasını seçmesidir (Kılıç, 2013). Örneklemin demografik özelliklerine baktığımızda; öğrencilerin ortaöğretim (lise) türlerinin \%64.7'sinin meslek liselerinin çocuk gelişimi bölümlerinden, \%26.8'inin düz lise, \%6.4'ünün meslek liselerinin çocuk gelişimi dışındaki bölümlerinden ve \%2.1'inin Anadolu lisesi mezunu olduğu görülmüştür. Üniversite eğitim kademeleri (sınıfları) dağılımına bakıldığında; \%38.9'u 1. sınıf, \%42.2'si 2. sınıf, \%11.2'si 4. sınıf ve \% 7.7'sinin 3. sinıf olduğu, çocuk haklarına dair bir ders alıp almama durumlarına bakıldığında ise \%43.5'inin çocuk haklarına dair bir ders aldıkları, \%56.5'inin ise çocuk haklarına dair bir ders almadıkları görülmüştür.

\section{Ölçeğin Geliştirilme Süreci}

Ölçek geliştirilirken; literatür tarama, madde havuzu oluşturma, uzman görüşü alma, uzman görüşü değerlendirme, ölçek puanlama, verilerin toplanması ve verilerin analizi süreçleri izlenmiştir.

\section{Madde havuzu oluşturma}

Maddelerin oluşturulması için literatür taraması yapılmış; belirgin şekilde Hart (1992) Katılım Merdiveni, Birleşmiş Milletler Çocuk Hakları Komitesi’nin (BM ÇHS) (2009) hazırladığı Genel Yorum 12: Katılım Hakkı ve Hodgkin ve Newell (2003) Çocuk Haklarına Dair Sözleşme Uygulama Kitabı göz önünde bulundurulmuş, çocuk hakları konusunda yapılan çalışmalar incelenerek 98 maddelik madde havuzu oluşturulmuştur.

\section{Uzman görüşü alma}

Maddeler dil, ifade ve anlatım düzeltmeleri için Türk Dili ve Edebiyatı bölümünden bir uzman araştırmacıya gönderilmiş, her bir maddenin anlam, dil ve ifade açısından değerlendirmesi istenmiştir. Uzman dönüşleri sonrası gerekli dil ve ifade düzeltmeleri yapılmış, bu aşamadan 
sonra maddeler alan uzmanlarının görüşüne sunulmak üzere form şeklinde hazırlanmıştır. Uzman görüşü sürecinde maddelerin hakem olarak kabul edilen test uzmanlarına ya da ilgili uzmanlara verilerek "ifadeler açık ve anlaşı1ır mı?”, "Konusuna uygun mu?”, "Doğru yanıtları çağrıştıran ipuçları var mı?” , “Ölçülmek istenen davranışa uygun mu?” vb. soruların yanıtları aranır (Öner, 2012). 98 maddelik katılım ile ilgili hazırlanan maddeler, çocuk gelişimi ve çocuk hakları konusunda çalışmaları bulunan çocuk gelişimi, çocuk gelişimi ve eğitimi ve okul öncesi öğretmenliği bölümlerinden, aralarında bir uzman, iki yardımcı doçent, üç profesör bulunan yedi alan uzmanına form halinde gönderilmiştir. Her bir maddeyi "amaca uygunluk" yani "çocuk katılımını temsil etme" durumlarına göre değerlendirmeleri; madde, belirtilen özelliği net olarak ölçmeye aday ise "Uygun", madde konu kapsamında ama düzeltilmesi ya da değiştirilmesi gerekiyor ise "Düzeltilmeli" , madde belirtilen özelliği ölçmüyor ise "Uygun Değil" seçeneklerini işaretlemeleri istenmiştir. Ayrıca görüş, önerileri ve madde eklemek için ek bir alan bırakılmıştır. 98 maddelik ölçek taslağı kamuya bağlı devlet üniversitesinin Etik Kurul Komisyonuna gönderilmiş ve etik kurul onayından geçmiştir.

\section{Uzman görüşü değerlendirme}

Uzman görüşleri Lawshe tekniği kullanılarak analiz edilmiştir. Bu teknik ile uzmanların bir maddeye ilişkin görüşleri alınarak kapsam geçerlik oranları elde edilir. Kapsam geçerlik oranları (KGO), maddeye dair "Gerekli” görüş bildiren uzman sayısının maddeye dair görüş belirten bütün uzmanların toplamının 1 eksiği ile hesaplanır (Yurdugül, 2005). Bu şekilde değerlendirilen uzman görüşleri sonrası 98 maddenin 41'i negatif ve 0 aralığında bulunarak ölçekten çıkarılmıştır. KGO değerleri negatif ya da 0 değer içeriyorsa böyle maddeler ilk etapta elenen maddelerdir. Kapsam geçerliliği için alt limit Veneziona ve Hooper'ın kapsam geçerlik ölçütleri tablosuna göre 0.99 olarak belirlenmiştir (Yurdugül, 2005). Bu doğrultuda ölçeğe 43 madde olduğu gibi geçmiş, gönderilen formda bulunmayan uzman önerileri doğrultusunda 2 madde eklenmiş, 10 madde öneriler doğrultusunda yeniden düzenlenmiştir. Yine öneriler doğrultusunda belirlenen maddeler anlam bakımında yakınlık derecesine göre sıralanmış ve 55 maddelik 5'li likert tipi bir ölçek ön formu oluşturulmuştur. Ön form, ölçek uygulama yönergesi hazırlanarak çalışma grubu dişında 15 öğrenciye ölçekte yer alan maddelerin cevaplayanlar tarafından anlaşılabilirliğini belirlemek üzere uygulanarak, pilot uygulama yapılmıştır. Pilot uygulama sonundaki değerlendirmeler doğrultusunda ölçek maddelerindeki ifadelerin değiştirilmesine gerek duyulmamıştır. 


\section{Ölçek puanlaması}

55 maddeden oluşan ölçek 5'li likert tipine göre, maddelere katılma durumlarına göre Kesinlikle Katılıyorum - Kesinlikle Katılmıyorum aralığında hazırlanmıştır. Likert (1932) tarafından geliştirilen dereceleme toplamlarıyla ölçekleme yaklaşımında, ölçülmek istenen söz konusu tutumla ilişkili çok sayıda olumlu ve olumsuz ifade, çok sayıda katılımcıya uygulanır (akt. Tezbaşaran, 2008). Likert'de, kararsızım, ne evet ne hayır, bazen katılıyor bazen katılmıyorum gibi seçenekler orta noktayı oluşturur. Fakat "bilmiyorum ve fikrim yok" kararsızım anlamına gelmez (Erdoğan, 2012). Likert tipi bir ölçekte, maddelere verilen cevapların puanlanışı öncelikle maddenin olumlu ya da olumsuz oluşuna bağlı olarak değişir. Olumsuz maddeler, olumlu maddelerin tersine puanlanır, böylece yüksek ölçek puanları daima olumlu tutumu gösterir (Tezbaşaran, 2008). Çocuk Katılımı Farkındalık Ölçeği puanlaması normal maddeler (27) ve ters maddeler (28) için farklı yapılmış; normal puanlama "Kesinlikle Katılıyorum" seçeneğinden başlayarak 5'ten 1'e doğru puanlanmış, olumsuz-ters puanlama ise “Kesinlikle Katılmıyorum” seçeneğinden başlayarak 5'ten 1'e doğru puanlanmıştır.

\section{Verilerin Toplanması ve Analizi}

27 normal ve 28 ters puanlanmış maddesi olan ölçeğin, birinci bölümde orta öğretim türü, üniversite kademesi-sınıfı, çocuk hakları ile ilgili bir ders alma durumu, anne-baba yaşı, anne baba öğrenim durumu gibi demografik bilgilere ilişkin sorular, ikinci bölümde ise çocuk katılımı ile ilgili ölçek maddeleri bulunmaktadır. Okul Öncesi Öğretmenliği ve Çocuk Gelişimi bölümü öğrenci popülasyonunun geneli kadınlardan oluştuğu düşünülerek ve dönem itibarı ile yaş aralıkları birbirine yakın olan öğrenciler olduğu varsayılarak cinsiyet ve yaş bilgisi istenmemiştir. Ölçek uygulama yönergesi ile 2016-2017 y1lı bahar döneminde İstanbul ilinde bulunan iki vakıf üniversitesinden Çocuk Gelişimi ve Okul Öncesi Öğretmenliği Bölümü öğrencilerinden 481 kişiye ulaşılmıştır. Uygulama sonrası cevap formları incelenmiş ve eksik veya birden fazla cevap bulunan ya da bunlar gibi çeşitli nedenlerle güvenilir bulunmayan formlar ( $\mathrm{n}=76)$ analiz dışı bırakılmıştır. Toplamda N=404 örneklem sayısı ile analizlere başlanmıştır. Örneklem sayısı, yapılan testler sonucu yeterli $(p=.000)$ bulunmuştur.

\section{BULGULAR}

Bu bölümde Çocuk Katılımı Farkındalık Ölçeğinin geliştirilmesi sürecinde yapılan analizler ve bu analizlere ilişkin yorumlara yer verilmiştir. 
Tablo 1. Normal dă̆glım analizi için Kolmogorov-Smirnov testi

\begin{tabular}{llc}
\hline Değerler & & Ölçek \\
\cline { 1 - 1 } $\mathrm{N}$ & & 404 \\
\cline { 1 - 1 } Normal Parametreler & & \\
\cline { 1 - 1 } Kolmogorov Smirnov Z & & 3.61 \\
$\mathrm{P}$ & & .296 \\
\hline
\end{tabular}

İstatistiksel analizlere geçilmeden önce toplanan verilerin normal dağılım gösterip göstermediğini belirlemek üzere Kolmogrov-Smirnov testi yapılmıştır. Tablo 1'de de görüldüğü gibi yapılan Kolmogorov-Smirnov testi sonucunda Çocuk Katılımı Farkındalık Ölçeğinin taslak formundan elde edilen puanların normal dağılım gösterdiği bulunmuştur $(\mathrm{p}>.05)$.

Tablo 2. KMO ve Barlett's testi değerleri

\begin{tabular}{llr}
\hline Kaiser-Meyer-Olkin Örneklem Yeterliliği & & .782 \\
& Ki-kare Değeri & 2597.798 \\
Barlett's Testi & Serbestlik Derecesi & 153 \\
& P & .000 \\
\hline
\end{tabular}

Verilerin, faktör analizi için uygunluğu Kaiser-Meyer-Olkin (KMO) katsayısı ve Barlett küresellik testi ile incelenebilir. Faktör oluşturabilmek için KMO'nun .60'dan yüksek olması beklenmekte, Barlett testi ise değişkenler arasında ilişki bulunup bulunmadığını kısmi korelasyonlar temelinde incelenmektedir (Büyüköztürk, 2016). KMO'nun .60'dan büyük olması aynı zamanda örneklem büyüklüğünü de vermektedir. Kaiser- Meyer- Olkin (KMO) ve Bartlett's Test, değişkenler arası ilişkinin gücünü ölçümler. KMO, faktör analizini istenen düzeyde yapılabilmesi için örneklemin 0.5 'den büyük olması beklenir (Karaalioğlu, 2015). Faktör analizi, birbiriyle alakalı çok sayıda değişkeni bir araya toplayarak az sayıda, ortak bir ad altında anlamlı yeni değişkenler (faktörler, boyutlar) bulmayı, keşfetmeyi amaçlayan çok değişkenli bir istatistiktir (Büyüköztürk, 2002). Kaiser- Meyer- Olkin (KMO) ve Bartlett's Test, değişkenler arası ilişkinin gücünü ölçümler. Tablo 2 'de de görüleceği gibi, dönüştürülmüş temel bileşenler analizinde faktörleştirilebilirlik için beklenen değere ulaşılmış, KMO değeri .78 bulunmuştur. Barlett's testi sonucu ise $(\mathrm{p}=.000 ; \mathrm{p}<.05)$ bulunmuş ve veri matrisinin uygun olduğunu göstermektedir. 
Tablo 3. Açıklanan toplam varyans miktarları

\begin{tabular}{|c|c|c|c|c|c|c|c|c|c|}
\hline \multirow{2}{*}{ 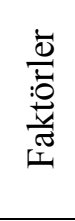 } & \multicolumn{3}{|c|}{ Başlangıç Öz Değerleri } & \multicolumn{3}{|c|}{ Toplam Faktör Yükleri } & \multicolumn{3}{|c|}{$\begin{array}{l}\text { Faktör Yüklerinin } \\
\text { Döndürülmüş Toplamları }\end{array}$} \\
\hline & Toplam & $\begin{array}{c}\text { Varyans } \\
\%\end{array}$ & $\begin{array}{c}\text { Kümülatif } \\
\%\end{array}$ & Toplam & $\begin{array}{c}\text { Varyans } \\
\%\end{array}$ & $\begin{array}{c}\text { Kümülatif } \\
\%\end{array}$ & Toplam & $\begin{array}{c}\text { Varyans } \\
\%\end{array}$ & $\begin{array}{c}\text { Kümülatif } \\
\%\end{array}$ \\
\hline 1 & 4.303 & 23.904 & 23.904 & 4.303 & 23.904 & 23.904 & 3.476 & 19.309 & 19.309 \\
\hline 2 & 3.182 & 17.676 & 41.580 & 3.182 & 17.676 & 41.580 & 2.596 & 14.424 & 33.733 \\
\hline 3 & 1.625 & 9.026 & 50.607 & 1.625 & 9.026 & 50.607 & 2.265 & 12.583 & 46.316 \\
\hline 4 & 1.372 & 7.620 & 58.226 & 1.372 & 7.620 & 58.226 & 1.702 & 9.445 & 55.770 \\
\hline 5 & 1.132 & 6.289 & 64.515 & 1.132 & 6.289 & 64.515 & 1.574 & 8.745 & 64.515 \\
\hline 6 & .879 & 4.883 & 69.398 & & & & & & \\
\hline$\cdots \cdot$ & $\cdots \cdots$ & $\ldots \ldots$ & $\ldots \ldots$ & & & & & & \\
\hline 18 & .230 & 1.279 & 100.000 & & & & & & \\
\hline
\end{tabular}

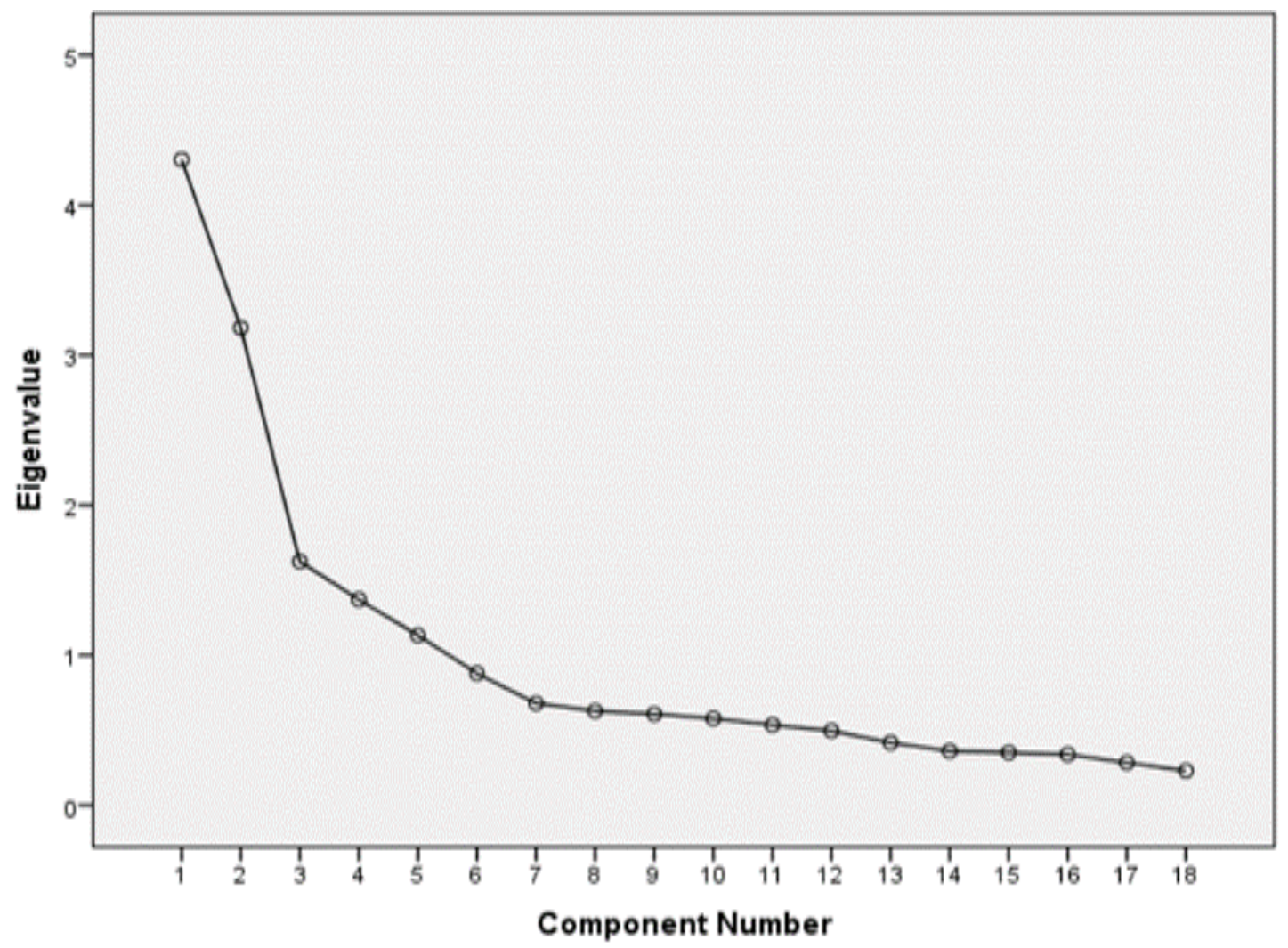

Şekil 1. Çocuk Katılımı Farkındalık Ölçeğindeki Maddelere İlişkin Yı̆̆glma Grafĭği

Tablo 3'te açıklanan toplam varyans miktarları ve Şekil 1'deki Çocuk Katılımı Farkındalık Ölçeğindeki maddelere ilişkin yığılma grafiği incelendiğinde, analiz edilen 18 değişkenin (maddenin) öz değeri 1'den büyük olan 5 faktör altında toplanmış ve bu 5 faktörün açıklanan 
toplam varyans miktarı \% 64.515 olarak bulunmuştur. Sırayla faktörlerin açıkladıkları varyans miktarlarına bakıldığında birinci faktör için \%23.904, ikinci faktör için \%17.676, üçüncü faktör için \%9.026, dördüncü faktör için \%7.620 ve beşinci faktör için \%6.289 olarak belirlenmiştir. Öz değer yükseldikçe, faktörün açıkladığı varyans da yükselmektedir (Tabachnick ve Fideli, 2001; Tatlidil, 1992; Büyüköztürk, 2002). Ancak, sosyal bilimlerde yapılan çalışmaların analizlerinde \%40 ile \%60 arasında olan varyans miktarları yeterli kabul (Scherer, Wiebe, Luther ve Adams, 1988; Tavşancıl, 2014) edildiği düşünüldüğünde elde edinilen varyans miktarının ideal olduğu söylenebilir. Analizde kuvvetli olan faktör sayısı, öz değer miktarlarına göre beş faktör olarak belirlenmiştir. Bu durum Çocuk Katılımı Farkındalık Ölçeğinin maddelere ilişkin yı̆̆ılma grafiğinde de açıkça görülmektedir.

Tablo 4. Faktör analizi sonucu dönüştürülmüs bileşenler matrisi

\begin{tabular}{|c|c|c|c|c|c|}
\hline \multirow{2}{*}{ Maddeler } & \multicolumn{5}{|c|}{ Faktörler } \\
\hline & 1 & 2 & 3 & 4 & 5 \\
\hline Madde32 & .807 & & & & \\
\hline Madde35 & .762 & & & & \\
\hline Madde33 & .760 & & & & \\
\hline Madde30 & .748 & & & & \\
\hline Madde31 & .671 & & & & \\
\hline Madde34 & .663 & & & & \\
\hline Madde5 & & .843 & & & \\
\hline Madde4 & & .818 & & & \\
\hline Madde3 & & .746 & & & \\
\hline Madde2 & & .671 & & & \\
\hline Madde27 & & & .837 & & \\
\hline Madde26 & & & .825 & & \\
\hline Madde28 & & & .596 & & \\
\hline Madde36 & & & .580 & & \\
\hline Madde13 & & & & .876 & \\
\hline Madde14 & & & & .804 & \\
\hline Madde24 & & & & & .857 \\
\hline Madde23 & & & & & .825 \\
\hline
\end{tabular}

Tablo 4 faktör analizi sonucu dönüştürülmüş bileşenler matrisi incelendiğinde 18 değişkenin yük değerinin .580 ve üzerinde olduğu görülmektedir. Varimax Dik Döndürme Tekniği kullanılarak değişkenlerin faktörlere dağılımına baktığımızda, en düşün yük değeri .580 ve en 
yüksek yük değeri .876 olan öz değeri 1'den büyük 5 faktörlü ölçekte bütün değişkenlerin girdikleri faktörlerde kabul edilebilir yük değerlerine sahip olduğu görülmüştür. Yine tabloda görüldüğü üzere birinci faktörde yer alan 6 değişkenin faktördeki yük değeri .663 - .807 arasında, ikinci faktörde yer alan 4 değişken için .671 - .843 arasında, üçüncü faktörde yer alan 4 değişken için .580 - .837 arasında bulunmuş, dördüncü faktörde yer alan 2 değişken için .804 ve .876 , beşinci faktörde yer alan 2 değişsen için ise faktördeki yük değerleri .825 ve .857 olarak bulunmuştur.

Tablo 5. Faktör analizi sonucunda belirlenen alt ölçekler ve bu ölçeklere ait maddeler

\begin{tabular}{lcl}
\hline \multicolumn{1}{c}{ Faktör } & Madde Sayıs1 & \multicolumn{1}{c}{ Madde Numaraları } \\
\hline 1. Katılımda Dekorasyon & 6 & $30,31,32,33,34,35$ \\
2. Katılımda Görüşe Sayg1 & 4 & $2,3,4,5$ \\
3. Katılımda Zorlama & 4 & $26,27,28,36$ \\
4. Katılımda Ayrım Gözetmeme & 2 & 13,14 \\
5. Katılımda Fizyolojik İhtiyaçlar & 2 & 23,24 \\
\hline
\end{tabular}

Tablo 5 faktör analizi sonucunda belirlenen alt ölçekler ve bu ölçeklere ait maddeler incelenerek oluşan alt ölçekler isimlendirilmiştir. 5 faktör ve 18 değişkenden oluşan ölçekte birinci faktör 6 değişkenden $(30,31,32,33,34,35)$; ikinci faktör 4 değişkenden $(2,3,4,5)$; üçüncü faktör 4 değişkenden $(26,27,28,36)$; dördüncü faktör 2 değişkenden $(13,14)$; beşinci faktör ise 2 değişkenden $(23,24)$ oluşmaktadır. Her bir faktör içine giren değişkenler incelenerek birinci alt ölçek Katılımda Dekorasyon alt ölçeğini; ikinci alt ölçek Katılımda Görüşe Saygı alt ölçeğini; üçüncü alt ölçek Katılımda Zorlama alt ölçeğini; dördüncü alt ölçek Katılımda Ayrım Gözetmeme alt ölçeğini; beşinci alt ölçek ise Katılımda Fizyolojik Ihtiyaçlar alt ölçeği olarak isimlendirilmiştir.

Birinci alt ölçek Katılımda Dekorasyon, çocukların hakkında hiçbir şey bilmeden, izinleri alınmadan ya da bilgilendirilmeden göstermelik izinlerin alındığı ya da çocuğu hiçe sayıp sadece aileler ile konuşulan olaylar, etkinlikler veya durumlarda dekor, süs hatta reklam malzemesi olarak kendi ve yaptıkları etkinlik resimlerinin kullanılmasını ifade eder. Bu alt ölçekteki tüm değişkenler ters puanlanır ve alt ölçek puanları $(\min =6, \max =30)$ olarak hesaplanır. İkinci alt ölçek Katılımda Çocuğun Görüşüne Saygl, çocukların görüşlerine her koşulda saygılı olmayı ve çocukların görüşlerini ifade edebilecekleri uygun ortam, zaman ve uyarıcı sağlanmasının gerekliliğini ifade eder. Bu alt ölçekteki tüm değişkenler normal 
puanlanır ve alt ölçek puanları $(\min =4, \max =20)$ olarak hesaplanır. Üçüncü alt ölçek Katılımda Zorlama, çocukların bir olay, durum veya konu hakkında herhangi bir bilgiye sahip olmadan sadece söyleneni yapmaları ile ilgilidir. Bu alt ölçek çocukların fikirleri alınmadan sınıf kurallarının, sınıf içi oturacakları yerlerin belirlenmesini ve yapılacak büyük hazırlık süreçleri olan gösterilere sorgusuz katılmalarını ifade eder. Bu alt ölçekteki tüm değişkenler ters puanlanır ve alt ölçek puanları $(\min =4, \max =20)$ olarak hesaplanır. Dördüncü alt ölçek Katılımda Ayrım Gözetmeme, çocukların her koşulda hiçbir ayrım gözetilmeden eşit şartlarda katılım fırsatlarına erişimi ile ilgilidir. Bu alt ölçek çocukların cinsiyetleri, etnik köken, ırkları göz önüne alınmadan yani ayrım yapılmadan eşit katılım firsatları yaratılmasını ifade eder. Bu alt ölçekteki tüm değişkenler normal puanlanır ve alt ölçek puanları ( $\min =$ 2, $\max =10$ ) olarak hesaplanır. Beşinci alt ölçek Katılımda Fizyolojik Ihtiyaçlar ise, çocukların fizyolojik ihtiyaçlarının etkinlikleri yarıda bırakması nedeniyle, çocukların ihtiyaç duydukları zaman değil öğretmenin belirlediği zamanlarda giderilmesi ile ilgilidir. Bu alt ölçek çocukların tuvalet ve su içme ihtiyaçlarının etkinliklere ya da öğretmene göre belirlenmesinin doğrudan katılım karşıtı olduğunu ifade eder. Bu alt ölçekteki tüm değişkenler ters puanlanır ve alt ölçek puanları $(\min =2, \max =10)$ olarak hesaplanır.

Çocuk Katılımı Farkındalık Ölçeği normal puanlanmış alt ölçekler (2 ve 4) ve ters puanlanmış alt ölçeklerden (1,3 ve 5) oluşmakta, Ters puanlanan değişkenler normal puanlanan değişkenlerin tersine puanlanmıştır. Normal puanlanan alt ölçeklerdeki tüm değişkenler "Kesinlikle Katılıyorum” seçeneğinden başlayarak "Kesinlikle Katılmıyorum” seçeneğine doğru 5'ten 1'e doğru puanlanmıştır. Ters puanlanan alt ölçeklerdeki tüm değişkenler ise "Kesinlikle Katılmıyorum” seçeneğinden başlayarak "Kesinlikle Katılıyorum” seçeneğine doğru 5'ten 1'e doğru puanlanmıştır. Dolayısıyla tüm alt ölçeklerde çıkacak yüksek puanların anlamı çocuk katılımı farkındalığının yüksek seviyede, düşük puanların anlamı ise çocuk katılımı farkındalığın düşük seviyede olduğunu gösterecektir. 5 alt ölçek ve 18 değişkenden oluşan Çocuk Katılımı Farkındalık Ölçeği maksimum puanı $90(18 \times 5)$ puan, minimum puanı ise $18(18 \times 1)$ puandır. Ölçek toplam puanları min18 ve min18'e yakın puanların çocuk katılımı konusundaki farkındalığın düşük $\max 90$ ve $\max 90^{\prime}$ a yakın puanların ise çocuk katılımı konusundaki farkındalığın yüksek olduğu şeklinde yorumlanır. Başka bir değişle öğrencilerin ölçek puanlarının düşük olması çocuk katılımı konusunda farkındalığın düşük 
düzeyde, puanların yüksek olması ise çocuk katılımı konusuna farkındalığın yüksek düzeyde olduğunu gösterir.

Tablo 6. Ölçeğin geneli ve alt ölçeklerine ait güvenirlik katsayıları

\begin{tabular}{lc}
\hline Faktör & CronBach's Alpha Değeri $(\alpha)$ \\
\hline 1. Katılımda Dekorasyon & .845 \\
2. Kat1lımda Görüş̧e Sayg1 & .784 \\
3. Katılımda Zorlama & .740 \\
4. Kat1lımda Ayrım Gözetmeme & .791 \\
5. Katılımda Fizyolojik İhtiyaçlar & .662 \\
Toplam & .802 \\
\hline
\end{tabular}

CronBach’s Alpha Değeri $(\alpha)$ elde edilen test puanları arasındaki içtutarlığı inceleme amacıyla kullanılır (Büyüköztürk, 2002). Tablo 6 incelendiğinde, ölçeğin toplam içtutarlık katsayısı $\alpha$ : .80 olarak hesaplanmıştır. Hesaplanan içtutarlık katsayısının kabul edilebilmesi için en az 0.70 olması beklenmektedir (Nunnally, 1978; Tavşancıl, 2014). Faktörlerin CronBach's Alpha değerlerine baktığımızda ise 1. faktör $\alpha:$.84; 2. faktör $\alpha:$.78; 3. faktör $\alpha:$.74; 4. faktör $\alpha: .79$; beşinci faktör ise $\alpha: .66$ olarak hesaplanmıştır, ölçek $\alpha: .66$ - $\alpha: .84$ aralığında değişmektedir. Özdamar (1999) da, Alpha katsayısının değerlendirilmesinde kullanılan değerlendirme ölçütü “ $0.60 \leq \alpha<0.80$ ise ölçek oldukça güvenilirdir.” şeklinde güvenilirlik düzeyini belirtilmekte (Tavşancıl, 2014) dolayısıyla bu değerler ölçeğin iç tutarlığının oldukça yüksek olduğunu göstermektedir.

Tablo 7. Ölçek alt ölçek ve toplam puanlarına ait ayırt ediciliklerini belirlemek için yapılan bağımsız gruplar t-testi sonuçları

\begin{tabular}{|c|c|c|c|c|c|c|c|}
\hline \multirow{2}{*}{ Puan } & \multirow{2}{*}{ Gruplar } & \multirow{2}{*}{$\mathrm{N}$} & \multirow{2}{*}{$\bar{X}$} & \multirow{2}{*}{ ss } & \multicolumn{3}{|c|}{$t$ testi } \\
\hline & & & & & $t$ & $\mathrm{sd}$ & $\mathrm{p}$ \\
\hline \multirow{2}{*}{ 1. Katılımda Dekorasyon } & Alt & 109 & 13.278 & 3.238 & \multirow{2}{*}{25.245} & \multirow{2}{*}{216} & \multirow{2}{*}{.000} \\
\hline & Üst & 109 & 25.260 & 3.750 & & & \\
\hline \multirow{2}{*}{ 2. Katılımda Görüşe Saygı } & Alt & 109 & 19.211 & 1.639 & \multirow{2}{*}{2.993} & \multirow{2}{*}{216} & \multirow{2}{*}{.003} \\
\hline & Üst & 109 & 19.734 & .800 & & & \\
\hline \multirow{2}{*}{ 3. Kat1lımda Zorlama } & Alt & 109 & 7.512 & 2.458 & \multirow{2}{*}{19.116} & \multirow{2}{*}{216} & \multirow{2}{*}{.000} \\
\hline & Üst & 109 & 14.691 & 3.054 & & & \\
\hline \multirow{2}{*}{ 4. Katılımda Ayrım Gözetmeme } & Alt & 109 & 9.697 & .833 & \multirow{2}{*}{2.137} & \multirow{2}{*}{216} & \multirow{2}{*}{.034} \\
\hline & Üst & 109 & 9.890 & .437 & & & \\
\hline
\end{tabular}




\begin{tabular}{lccccccc}
\hline \multirow{2}{*}{ 5. Katılımda Fizyolojik İhtiyaçlar } & Alt & 109 & 6.248 & 2.059 & \multirow{2}{*}{0.913} & 216 & .000 \\
\hline \multirow{2}{*}{ Ölçek Toplam } & Üst & 109 & 8.551 & 1.739 & & & \\
\hline & Alt & 109 & 55.947 & 4.265 & \multirow{2}{*}{39.813} & 216 & .000 \\
\hline
\end{tabular}

Çocuk Katılımı Farkındalık Ölçeği alt ölçek ve toplam puanlarına ait ayırt ediciliklerini belirlemek için yapılan bağımsız gruplar $t$-testi toplam alt-üst grupların sonucuna $(t=$ 39.813; $\mathrm{p}<.001)$ göre örneklem ortalamaları arasında üst grup lehine anlamlı bir fark bulunmuştur. Tablo 7'de de görüldüğü üzere faktörler arasında üst grup lehine farklılık $(\mathrm{p}<$ .001) anlamlı bulunmuş ve sonuçların yapılan bağımsız gruplar $t$-testine göre ayırt edici olduğu görülmektedir. $t$-testi, iki ilişkisiz örneklemin ortalamaları arasındaki farkın anlamlı çıkıp çıkmayacağını test etmek için kullanılmaktadır (Büyüköztürk, 2016).

Tablo 8. Madde toplam ve madde kalan korelasyon sonuçları

\begin{tabular}{lccccc}
\hline & \multicolumn{2}{c}{ Madde Toplam } & \multicolumn{2}{c}{ Madde Kalan } \\
Maddeler & $\mathrm{N}$ & $\mathrm{r}$ & $\mathrm{P}$ & $\mathrm{r}$ & $\mathrm{p}$ \\
\hline Madde32 & & .627 & .000 & .511 & .000 \\
Madde35 & 404 & .613 & .000 & .516 & .000 \\
Madde33 & 404 & .701 & .000 & .613 & .000 \\
Madde30 & 404 & .640 & .000 & .553 & .000 \\
Madde31 & 404 & .602 & .000 & .525 & .000 \\
Madde34 & 404 & .671 & .000 & .582 & .000 \\
Madde5 & 404 & .252 & .002 & .201 & .002 \\
Madde4 & 404 & .258 & .001 & .221 & .000 \\
Madde3 & 404 & .239 & .005 & .204 & .001 \\
Madde2 & 404 & .266 & .001 & .227 & .000 \\
Madde27 & 404 & .555 & .000 & .442 & .000 \\
Madde26 & 404 & .565 & .000 & .445 & .000 \\
Madde28 & 404 & .536 & .000 & .443 & .000 \\
Madde36 & 404 & .605 & .000 & .506 & .000 \\
Madde13 & 404 & .293 & .000 & .264 & .001 \\
Madde14 & 404 & .260 & .000 & .222 & .001 \\
Madde24 & 404 & .416 & .004 & .285 & .000 \\
Madde23 & 404 & .394 & .000 & .284 & .000 \\
\hline
\end{tabular}


Tablo 10. Test tekrar test güvenirliği için yapılan pearson momentler çarpımı korealsyon ve bağımlı gruplar t-testi sonuçları

\begin{tabular}{|c|c|c|c|c|c|c|c|c|c|}
\hline \multirow{2}{*}{ Faktör } & \multirow{2}{*}{ Uygulama } & \multirow{2}{*}{$\mathrm{N}$} & \multirow{2}{*}{$\bar{X}$} & \multirow{2}{*}{ Ss } & \multirow{2}{*}{$\mathrm{r}$} & \multirow{2}{*}{$\mathrm{p}$} & \multicolumn{3}{|c|}{ t Testi } \\
\hline & & & & & & & $\mathrm{t}$ & sd & $\mathrm{p}$ \\
\hline \multirow{2}{*}{ 1. Katılımda Dekorasyon } & Birinci & 153 & 14.386 & 5.202 & \multirow{2}{*}{.828} & \multirow{2}{*}{.000} & \multirow{2}{*}{-.956} & \multirow{2}{*}{152} & \multirow{2}{*}{.341} \\
\hline & İkinci & 153 & 14.628 & 5.441 & & & & & \\
\hline \multirow{2}{*}{ 2. Katılımda Görüşe Sayg1 } & Birinci & 153 & 19.523 & .827 & \multirow{2}{*}{.327} & \multirow{2}{*}{.000} & \multirow{2}{*}{1.922} & \multirow{2}{*}{152} & \multirow{2}{*}{.057} \\
\hline & İkinci & 153 & 19.327 & 1.261 & & & & & \\
\hline \multirow{2}{*}{ 3. Katılımda Zorlama } & Birinci & 153 & 11.170 & 3.816 & \multirow{2}{*}{.817} & \multirow{2}{*}{.000} & \multirow{2}{*}{-.655} & \multirow{2}{*}{152} & \multirow{2}{*}{.514} \\
\hline & İkinci & 153 & 11.300 & 4.244 & & & & & \\
\hline \multirow{2}{*}{$\begin{array}{l}\text { 4. Katılımda Ayrım } \\
\text { Gözetmeme }\end{array}$} & Birinci & 153 & 9.910 & .505 & \multirow{2}{*}{.507} & \multirow{2}{*}{.000} & \multirow{2}{*}{1.850} & \multirow{2}{*}{152} & \multirow{2}{*}{.066} \\
\hline & İkinci & 153 & 9.804 & .803 & & & & & \\
\hline \multirow{2}{*}{$\begin{array}{l}\text { 5. Katılımda Fizyolojik } \\
\text { İhtiyaçlar }\end{array}$} & Birinci & 153 & 4.778 & 1.854 & \multirow{2}{*}{.628} & \multirow{2}{*}{.000} & \multirow{2}{*}{-.514} & \multirow{2}{*}{152} & 608 \\
\hline & İkinci & 153 & 4.843 & 1.789 & & & & & \\
\hline Ölcek Tonl & Birinci & 153 & 59.765 & 8.850 & 864 & 000 & -355 & 152 & 723 \\
\hline Uіс̧ек Iорram & İkinci & 153 & 59.902 & 9.375 & & & - & & \\
\hline
\end{tabular}

Ölçeğin test-tekrar test güvenirliğini sınamak için çalışma grubunda yer almayan 153 Çocuk Gelişimi öğrencisine Çocuk Katılımı Farkındalık Ölçeği 3 hafta (21 gün) arayla uygulanmıştır. Bir ölçeğin zamana karşı değişmediğini belirlemek için hesaplanan korelasyon miktarının pozitif ve yüksek olması beklenir (Tavşancıl, 2014). Tablo 10 Pearson Momentler çarpımı korealsyon ve t-testi sonucunda en düşük korelasyonun faktör 2 'de $(r=.327 ; p<.05)$; en yüksek korelasyon faktör 1 'de $(r=.828 ; p<.05)$ olarak bulunmuş; toplam korelasyon ise $(r=.864 ; p<.05)$ olarak bulunmuş ve iki uygulama arasında t-testi sonucuna göre anlamlı farklılığın olmadığı görülmektedir. Bu sonuç doğrultusunda ölçeğin pozitif yönde anlamlı olduğunu, zamana karşı değişmeden farklı uygulamalar sonrasında kararlılık gösterdiği söylenebilir.

Araştırma kapsamında kullanılan Çocuk Katılımı Farkındalık Ölçeğinin yapı geçerliğini incelemek amacıyla Doğrulayıcı Faktör Analizi (DFA) yapılmıştır. DFA'nın varsayımları; örneklem büyüklüğü, kayıp değerler, normallik, doğrusallık, çoklu bağlantı ve tekillik ve uç değerler şeklinde sıralanabilir.

Tablo 11. Çocuk katılımı farkındalık ölçeği için hesaplanan KMO değerleri

\begin{tabular}{ll}
\hline KMO & $\mathrm{p}$ \\
\hline .77 & .000 \\
\hline
\end{tabular}


Öncelikle uç değer olan 1 veri, veri setinden çıkarılmış ve 152 kişiye ait veriyle analize devam edilmiştir. Örneklem büyüklügü için KMO testi yapılmıştır. Araştırma kapsamında hesaplanan KMO sonuçları Tablo 11'de verilmiştir. Kline (2005), 100-200 arasındaki örneklem büyüklüğünü kabul edilebilir olarak değerlendirmiştir. Leech, Barrett ve Morgan'a (2005) göre ise KMO değerinin .70 ve üzerinde olması örneklem büyüklüğünün orta düzeyde kabul edilebilir olduğunu göstermektedir. Kolmogorov-Smirnov testi sonuçlarına göre ölçek normal dağılım göstermektedir ( $\mathrm{p}>.05)$. Ayrıca çarpıklık değerli -1 ile +1 değerleri arasındadır (-.36). Bu durumda ölçekten elde edilen puanların normal dağılım gösterdiği şeklinde yorumlanmıştır. Tabachnick ve Fidell (2001) faktör sayısını saptamak ya da doğrulamak istendiğinde çok değişkenliğin olduğu sayıltısının kullanılmasını önermektedir. Bu araştırmada da bu sayıltı kullanılmıştır. Varsayımların test edilmesinden sonra DFA analizine geçilmiştir.

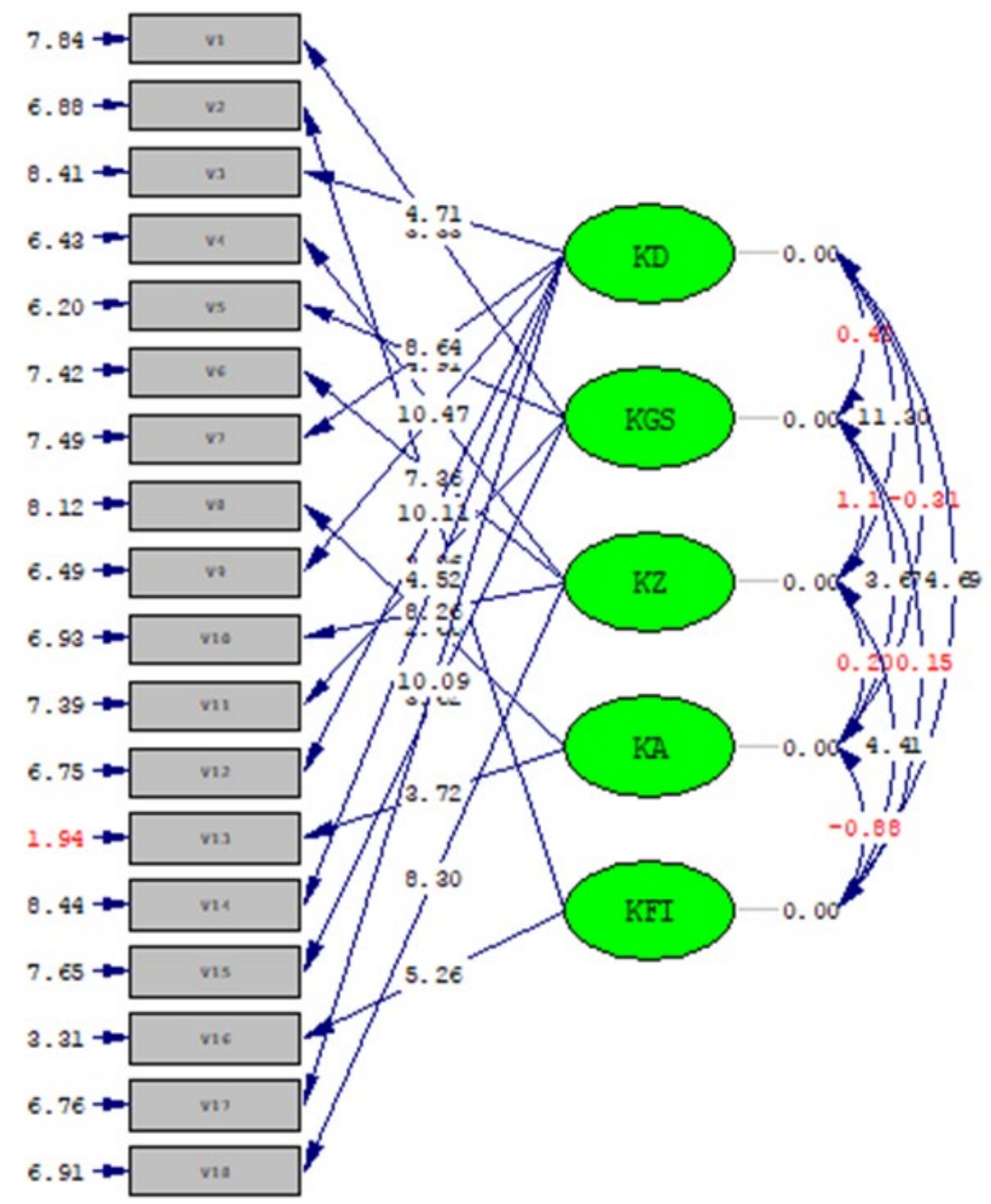

Chi-Square $=172.19, d f=125, p-v a l u e=0.00330, \mathrm{RM} E \mathrm{~A}=0.050$

Şekil 2. Çocuk Katılımı Farkındalık Ölçeği DFA T Dĕgerleri 
Şekil 2'de de görüldüğü üzere DFA'da ilk olarak t değerleri incelenmiştir. T değerinin 1.96'y1 aşması .05 düzeyinde, 2.56’yı aşması ise .01 düzeyinde anlamlı olduğunu göstermektedir. T değerlerine göre 11. madde hariç tüm maddeler .01 düzeyinde anlamlıdır. 11. maddenin $t$ değeri ise kritik değer olan 1.96'nın hemen altında 1.94'tür. Bu gizil değişkenlerin gözlenen değişkenleri doğru bir şekilde açıkladığını göstermektedir.

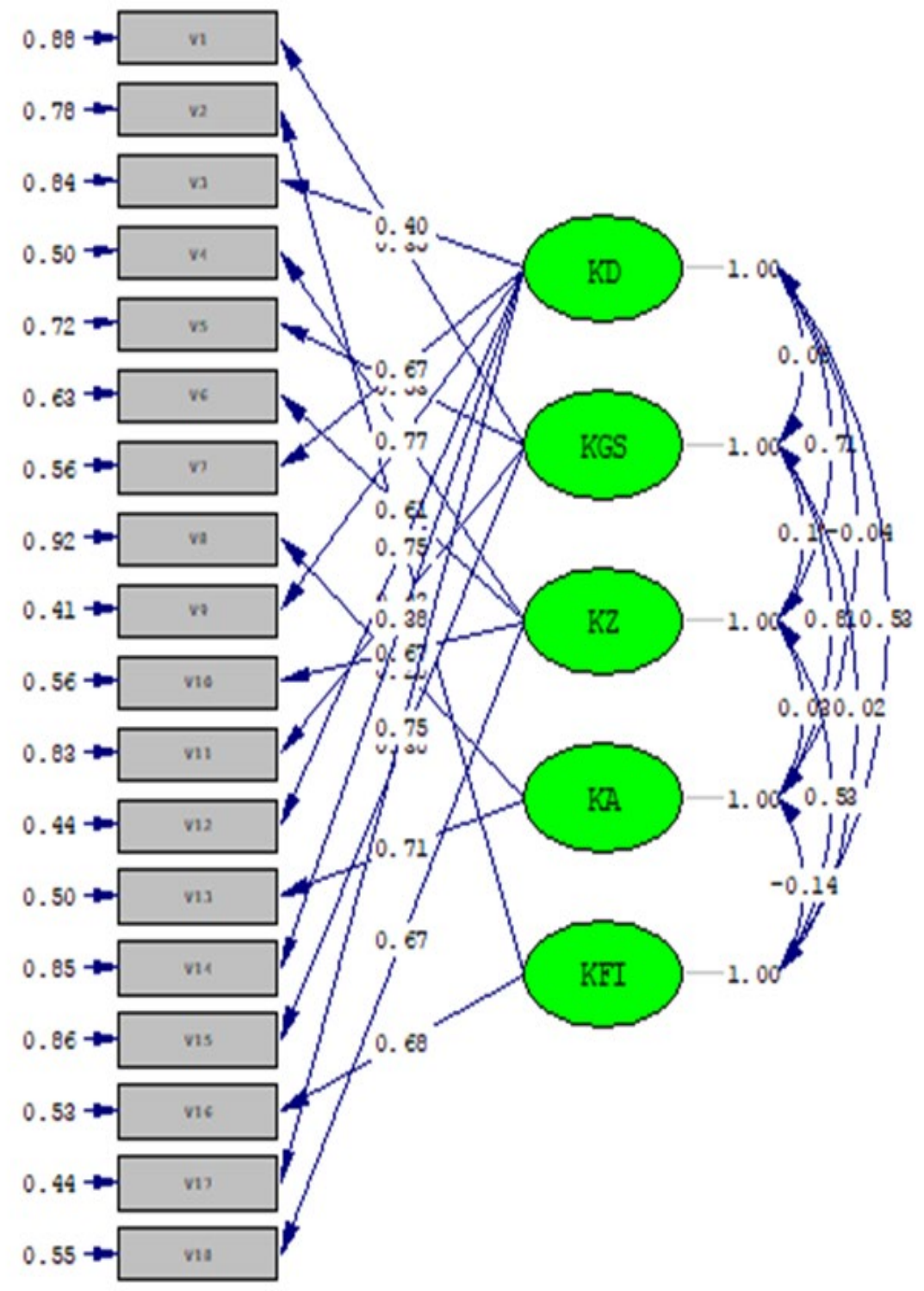

Chi-Square $=172.19, \mathrm{df}=125, \mathrm{p}-\mathrm{value}=0.00330, \mathrm{RMSEA}=0.050$

\section{Şekil 3. Çocuk Katılımı Farkındalık Ölçeği DFA Standartlaştırılmış Çözüm Sonuçları}

Daha sonra standartlaştırılmış çözüm değerleri incelenmiştir. Şekil 3'de maddelerin solunda yer alan değerler hata varyanslarını göstermektedir. Burada 8. madde hariç tüm maddelerin hata varyansları küçük olarak değerlendirilebilir. Şekil 3'de de görüldüğü üzere değerler .41 ile .92 
arasında bulunmuş, iki sonuca göre de sadece birer maddenin hatalarının yüksek olduğu, diğer maddelerin hatalarının ise düşük olduğu görülmektedir.

Tablo 12. Çocuk Katılımı Farkındalık Ölçeği DFA sonuçlarına ilişkin uyum iyiliği değerleri

\begin{tabular}{llll}
\hline \multicolumn{1}{c}{ İndeksler } & \multicolumn{1}{c}{$\begin{array}{c}\text { Maddelere İlişkin } \\
\text { Değerler }\end{array}$} & Mükemmel Uyum & İyi uyum \\
\hline $\begin{array}{l}\chi^{2} \\
\text { sd }\end{array}$ & 172.19 & \\
\hline $\mathrm{p}$ & 125 & & \\
\hline$\chi^{2} / \mathrm{sd}$ & .0033 & $\chi^{2} / \mathrm{sd} \leq 3.00$ & $3.00<\chi^{2} / \mathrm{sd} \leq 8.00$ \\
\hline RMSEA & 1.38 & $0 \leq \mathrm{RMSEA} \leq .05$ & $.05<\mathrm{RMSEA} \leq .08$ \\
\hline RMSEA $(.90 \mathrm{GA})$ & $.030-.067$ & & \\
\hline SRMR & .062 & $0 \leq \mathrm{SRMR} \leq .05$ & $.05<\mathrm{SRMR} \leq .10$ \\
\hline GFI & .89 & $.95 \leq \mathrm{GFI} \leq 1.00$ & $.90 \leq \mathrm{GFI}<.95$ \\
\hline AGFI & .85 & $.90 \leq \mathrm{AGFI} \leq 1.00$ & $.85 \leq \mathrm{AGFI}<.90$ \\
\hline CFI & .95 & $.97 \leq \mathrm{CFI} \leq 1.00$ & $.95 \leq \mathrm{CFI}<.97$ \\
\hline NFI & .85 & $.95 \leq \mathrm{NFI} \leq 1.00$ & $.90 \leq \mathrm{NFI}<.95$ \\
\hline NNFI & .94 & $.97 \leq \mathrm{NNFI} \leq 1.00$ & $.95 \leq \mathrm{NNFI}<.97$ \\
\hline
\end{tabular}

Doğrulayıcı faktör analizinde uyum iyiliği indekslerini de incelemek gerekmektedir. Uyum iyiliği değerleri ile ilgili değerler için tablo 12 incelendiğinde, Çocuk Katılımı Farkındalık Ölçeği'nde yer alan maddelere ait uyum iyiliği değerlerinin tablonun solunda, alınan ölçüt değerlerin ise tablonun sağdaki iki sütununda yer aldığı görülmektedir. $\chi^{2}$.01 düzeyinde anlamlı bulunmuştur. Bu uyumun olmadığı anlamına gelmektedir ancak örneklem büyüdükçe $\chi^{2}$ anlamlı çıkabilmektedir. Bu yüzden $\chi^{2}$ nin serbestlik derecesine bölümünden elde edilen 1.38 değeri mükemmel uyumu göstermektedir. RMSEA mükemmel uyumu göstermektedir. SRMR, AGFI, CFI iyi uyumu göstermektedir. GFI, NFI ve NNFI iyi uyumun hemen altında değer almıştır. Bütüncül bir değerlendirme yapıldığında Çocuk Katılımı Farkındalık Ölçeğinin maddelerinin genel olarak kabul edilebilir uyumu gösterdikleri ifade edilebilir.

Ölçeğin asıl uygulaması kapsamında yapılan güvenirlik analizi sonucunda elde edilen Cronbach'ın $\alpha$ katsayısı .80 olarak hesaplanmıştır. $\mathrm{Bu}$ değer güvenirliğin iyi olduğunu göstermektedir. 


\section{SONUÇ ve TARTIŞMA}

Araştırmada çocuk gelişimi ve okul öncesi öğretmenliği bölümünde okuyan öğrencilerin çocuk hakları bağlamında katılım hakkı ile ilgili görüşlerini belirlemek amacı ile geliştirilen literatür taraması sonucu oluşturulmuş 98 maddelik ölçme aracı alanında uzman 7 kişiye gönderilerek yorum ve görüşleri doğrultusunda ölçeğe 43 madde olduğu gibi geçmiş, gönderilen formda bulunmayan uzman önerileri doğrultusunda 2 madde eklenmiş, 10 madde öneriler doğrultusunda düzenlenmiştir yine öneriler doğrultusunda belirlenen maddeler anlam bakımında yakınlık derecesine göre sıralanmış ve 55 maddelik 5'li likert tipi bir ölçek ön formu oluşturulmuştur.

Araştırmada faktörleştirebilirlik için yapılan dönüştürülmüş temel bileşenler analizinde KMO değeri .78, Barlett's testi sonucu ise 2597.798 bulunmuş, analize alınan 18 değişken öz değeri 1 'den büyük olan 5 faktör altında toplanmıştır. Bu 5 faktörün açıklanan toplam varyans miktarı \%64.515 olarak bulunmuş, faktör yükleri ise .569 - .876 arasında değişmektedir. Faktör sırayla katılımda dekorasyon, katılımda görüşe saygı, katılımda zorlama, katılımda ayrım gözetmeme ve katılımda fizyolojik ihtiyaçlar olarak isimlendirilmiştir. Tüm ölçeğin içtutarlık katsayısı $\alpha$ : .80 olarak hesaplanmıştır. $\alpha$ katsayı değerinin .70'den büyük olması ölçeğin kendi içinde tutarlı olduğunu göstermektedir (Nunnally, 1978; Tavşanc1l, 2014). Ölçek alt ölçek ve toplam puanlarına ait ayırt ediciliği belirlemek üzere yapılan analiz sonuçlarına göre alt ölçek ve toplam puanlarının ayırt edici olduğunu tüm gruplar için farklılıkların istatistiksel olarak anlamlı bulunmuş olması $(\mathrm{t}=39.813 ; \mathrm{p}<.03)$ ortaya koymuştur. .20'den büyük olması beklenen (Yalın Sapmaz, ve diğerleri, 2016) madde toplam puan korelasyon analizi sonuçlarına göre madde toplam korelasyon katsayıları .24 ile .70 arasında, madde kalan korelasyon katsayıları ise .20 ile .61 arasında değişmekte ve istatistiksel olarak anlamlıdır. Faktörler arası ilişkiyi belirlemek üzere yapılan pearson momentler çarpımı korelasyon analizi sonuçlarına göre tüm faktörler arasında pozitif yönde anlamlı bir ilişki olduğu görülmüş, tüm faktörlerin birbiri ile ilişkili olduğu sonucuna varılmıştır. Son olarak test tekrar test güvenirliği için yapılan Pearson Momentler çarpımı korealsyon ve bağımlı gruplar t-testi sonucunda toplam korelasyon katsayısı $(r=.864 ; p<.05)$ olarak bulunmuştur, bu sonuç doğrultusunda söylenebilir ki ölçek zamana karşı değişmeden farklı uygulamalar sonrasında tutarlılık ve kararlılık göstermektedir. 
Araştırma kapsamında kullanılan Çocuk Katılımı Farkındalık Ölçeğinin yapı geçerliğini incelemek amacıyla Doğrulayıcı Faktör Analizi (DFA) yapılmıştır. Normallik için ölçek maddelerinden toplam puan alınmış, Kolmogorov-Smirnov testi yapılmış, çarpıklık değerleri incelenmiştir. Kolmogorov-Smirnov testi sonuçlarına göre ölçek normal dağılım göstermektedir ( $\mathrm{p}>$.05). Yapılan DFA sonucu t değerinin 1.96'yı aşması .05 düzeyinde, 2.56'y1 aşması ise .01 düzeyinde anlamlı olduğunu göstermektedir. T değerlerine göre 11. madde hariç tüm maddeler .01 düzeyinde anlamlıdır. 11. maddenin t değeri ise kritik değer olan 1.96'nın hemen altında 1.94'tür. Bu gizil değişkenlerin gözlenen değişkenleri doğru bir şekilde açıkladığını göstermektedir. Standartlaştırılmış çözüm değerlerine bakıldığında 8. madde hariç tüm maddelerin hata varyansları küçük olarak değerlendirilmiş, değerler .41 ile .92 arasında bulunmuştur. Çocuk Katılımı Farkındalık Ölçeği DFA sonuçlarına ilişkin uyum iyiliği değerlerine baktığımızda RMSEA mükemmel uyumu göstermektedir. SRMR, AGFI, CFI iyi uyumu göstermektedir. GFI, NFI ve NNFI iyi uyumun hemen altında değer aldığ1 görülmektedir.

Tüm analizler sonunda Çocuk Katılımı Farkındalık Ölçeğinin, çocuk gelişimi ve okul öncesi öğretmenliği öğrencilerinin çocuk hakları bağlamında katılım hakkı ile ilgili görüşlerini belirlemede geçerli ve güvenilir biçimde kullanılabilecek bir ölçme aracı olduğu görülmektedir. Türkiye'de çocukların katılım hakkı ile ilgili tutumları ölçmeye yönelik ölçek çalışmasına rastlanmamıştır. Fakat çeşitli aşamalar izlenerek geliştirilen ölçek, diğer ölçek çalışmaları ile karşılaştırıldığında; Acar Güvendir ve Özer Özkan (2015) tarafından yapılan çalışmada 20062014 yılları arasında Türkiye'deki eğitim alanında yayımlanan bilimsel dergilerde ölçek geliştirme ve uyarlama sürecinde kullanılan aşamaların belirlenmesi amaçlamış makalelerde süreçte izlenen adımlar incelenmiş, benzerlik ve farklılıklara bakılmıştır. Araştırmaya göre ölçek geliştirme konulu makalelerde önerilen ve izlenen aşamalara uygun bir çalışma yapıldığ düşünülmektedir. Hem konu yakınlığı hem de ölçek geliştirme çalışması olması amacıyla Karaman Kepenekçi (2006) üniversite öğrencilerinin çocuk hakları konusundaki tutumlarını ölçmek için Çocuk Hakları Tutum Ölçeği (ÇHTÖ) adlı likert tipi bir ölçek geliştirmiş, bu çalışmada da 300 üzerinde gönüllü katılımcı ile çalışılmış, ölçeğin geçerlik ve güvenilirliğini belirlemek için faktör analizi tekniği ve cronbach alfa formülü kullanmış ve her bir madde için madde toplam korelasyonu hesaplanmış; her iki çalışmada ölçek geliştirme sürecinde benzer aşamaları izlemiştir.

Erken Çocukluk Çalıșmaları Dergisi

Cilt $1 \cdot$ Say1 $2 \cdot$ Ekim
Journal of Early Childhood Studies

Volume 1 - Issue 2 - October 
Türkiye'de çocukların katılım hakkı ile ilgili farkındalık ölçmeye yönelik ölçek çalışması bulunmamakta, geliştirilen Çocuk Katılımı Farkındalık Ölçeğinin bu eksikliği giderebileceği ve literatüre katkı sağlayacağı düşünülmektedir. Ayrıca çocukların haklarının farkında olması, haklarını bilerek yaşamlarına uyarlaması ve ona uygun yaşamaları hem Çocuk Haklarına Dair Sözleşmeye hem de Çocuk Hakları Komitesi'ne göre önemli ve gereklidir. Bu doğrultuda çocuklara doğrudan çalışacak okul öncesi öğretmenliği ve çocuk gelişimi öğrencilerinin katılım hakları konusundaki görüşleri ve uygulamaları önemli yer tutmaktadır. Geliştirilen ölçek sadece bu alan öğrencilerine değil, eğitim fakültelerindeki öğrencilere, alan çalışanlarına, ailelere ve çocuklarla bir şekilde bir arada olan her gruba uygulanabilir. Bu çerçevede uygulama grupları ile ilgili uyarlama çalışmaları yapılabilir.

\section{KAYNAKÇA}

Acar Güvendir, M., \& Özer Özkan, Y. (2015). Türkiye'de eğitim alanında yayımlanan bilimsel dergilerde ölçek geliştirme ve uyarlama konulu makalelerin incelenmesi. Elektronik Sosyal Bilimler Dergisi, 14(52), 23-33. http://dergipark.ulakbim.gov.tr/esosder/article/view/5000086077 adresinden alınd1

Adhikari, H. (2016). Children's participation decision making process in the family affairs of female commercial sex workers(FCSWS) and its' impact. Journal of Alternative Perspectives in the Social Sciences, 8(1), 99-111. http://www.japss.org/upload/5.\%20Adhikari.pdf adresinden alınd1

Akyüz, E. (2015). Çocuk hukuku. Ankara: Pegem Akademi.

Birleşmiş Milletler Çocuk Hakları Komitesi. (2009). Birleşmiş milletler çocuk hakları komitesi'nin çocuk haklarına dair sözleşme'ye ilişkin genel yorumları 2008-2011. Ankara: Uluslararası Çocuk Merkezi ICC Çocuk Hakları Serisi 10.

Büyüköztürk, Ş. (2002). Faktör analizi temel kavramlar ve ölçek geliştirmede kullanımı. Kuram ve Uygulamada Eğitim Yönetimi Dergisi(32), 470-483. http://kuey.net/index.php/kuey/article/view/517/330 adresinden alınd1

Büyüköztürk, Ş. (2016). Sosyal bilimler için veri analizi el kitabı. Ankara: Pegem Akademi.

Erbay, E. (2013). Çocuk hakları. İstanbul: Yeni İnsan Yayınevi.

Erbay, E. (2013). Çocukların katılım hakkı üzerine bir türkiye değerlendirmesi. İnsan ve Toplum Bilimleri Araştırmalarl Dergisi, 2(1), 38-54. http://www.itobiad.com/download/article-file/92695 adresinden alındı

Erdoğan, İ. (2012). Pozitivist metodoloji ve ötesi araştırma tasarımları niteliksel ve istatistiksel yöntemler. Ankara: Erk Yayınları.

Flowers, N. (2010). Pusulacık çocuklar için insan hakları eğitimi kılavuzu. İstanbul: İstanbul Bilgi Üniversitesi Yayınları.

Franklin, B. (1993). Çocuk hakları. İstanbul: Ayrıntı Yayınları. 
Hart, R. A. (1992). Children's participation: from tokenism to cittzenship. Florence, Italy: Unicef. https://www.unicef-irc.org/publications/pdf/childrens_participation.pdf adresinden alındı

Hart, R. A. (2016). Çocukların katılımı: kuram ve uygulamada toplum gelişimi ve çevre korumasında genç yurttaşları içrmek. Ankara: Nobel.

Hodgkin, R., \& Newell, P. (2003). Çocuk haklarına dair sözleşme uygulama el kitabı. New York, USA:

UNICEF. http://www.unicef.org.tr/files/bilgimerkezi/doc/Uygulama\%20Elkitabi\%20TR.pdf adresinden alind 1

Karaalioğlu, Z. (2015). SPSS'dE output analizi. İstanbul: İstanbul Ticaret Üniversitesi. http://ders.es/kmo_barlett_testi.docx adresinden alındı

Karaman Kepenekçi, Y. (2006). A study of university students' sttitudes towards children's rights in turkey. The International Journal of Children's Rights, 14(3), 307-318. http://booksandjournals.brillonline.com/content/journals/10.1163/1571818067784580 95 adresinden alındı

Kılıç, S. (2013). Örnekleme yöntemleri. Journal of Mood Disorders, 3(1), 44-46. http://scholar.googleusercontent.com/scholar?q=cache:zuSVkZ2U6NUJ:scholar.googl e.com/+geli\%C5\%9Fig\%C3\%BCzel+\%C3\%B6rnekleme\&hl=tr\&as_sdt=0,5 adresinden alınd.

Kline, R. B. (2005). Principles and Practice of Structural Equation Modeling. (Second Edition). NY: Guilford Publications, Inc.

Koran, N. (2012). Okul öncesi öğretmenlerinin çocukların katılım hakkı konusundaki uygulamalarının ögretmen adayı gözlemlerine göre incelenmesi. Girne: Yüksek lisans tezi. Girne Amerikan Üniversitesi, Sosyal Bilimler Enstitüsü.

Leech, N. L., Barrett, K. C., \& Morgan, G. A. (2005). SPSS for intermediate statistics: Use and interpretation. Mahwah, N.J: Lawrence Erlbaum.

Merey, Z. (2016). Çocuk hakları. Ankara: Pegem Akademi.

Moroğlu, N. (2003). Ulusal ve uluslararası hukukta çocuk hakları. II. Eğitim Paneli (s. 29-38). İstanbul: Alman Liseliler Kültür ve Eğitim Vakfi.

Öner, N. (2012). Türkiye'de kullanılan psikolojik testlerden örnekler. İstanbul: Boğaziçi Üniversitesi Yayınevi.

Özdemir, A. (2016). Yönetim biliminde ileri araştırma yöntemleri ve uygulamalar. İsatanbul: Beta Yayıncilik.

Polat, O., \& Şahin, S. (2012). Türkiye'de ve dünyada gelişmiş ülkelerde çocuk katılım hakkı algısının ve uygulamalarının karşılaştırılması. Hukuk ve İktisat Araştırmaları Dergisi, 4(1), 275-282. http://www.sobiad.org/ejournals/dergi_hia/arsiv/2012/sultan_sahin.pdf adresinden alınd

Tabachnick B. G. and Fidel, L. S. (2001). Using Multivariate Statistics. (Fourth Edition). MA: Allyn \& Bacon, Inc.

Talay, İ., Aslan, F., \& Belkayalı, N. (2010). Okul öncesi eğitim kurumlarında doğa dostu ve çocuk katılımı temelli dış mekan tasarım yaklaşımları bir proje önerisi. Kastamonu 
Eğitim Dergisi, $18(1), \quad 317-322 . \quad$ http://www.kefdergi.com/pdf/18_1/18_23.pdf adresinden alind

Tavşanc1l, E. (2014). Tutumların ölçülmesi ve SPSS ile veri analizi. Ankara: Nobel.

Tezbaşaran, A. A. (2008). Likert tipi ölçek hazırlama kılavuzu. Mersin. https://www.academia.edu/1288035/Likert_Tipi_\%C3\%961\%C3\%A7ek_Haz\%C4\%B 1rlama_K\%C4\%B1lavuzu adresinden alındı

UNICEF. (2004). Çocuk haklarına dair sözleşme. Türkiye: UNICEF.

UNICEF. (2009). Dünya çocuklarının durumu. UNICEF.

Yalçın, S. (2016). Korelasyon, korelasyon türleri ve regresyon. https://acikders.ankara.edu.tr: https://acikders.ankara.edu.tr/pluginfile.php/2154/mod_resource/content/2/konu8a.pdf adresinden alınd 1

Yalın Sapmaz, Ş., Sargın, E., Ergin, C., Özek Erkuran, H., Öztürk, M., \& Aydemir, Ö. (2016). DSM-5 düzey 2 madde kullanımı ölçeğinin türkçe formunun güvenirliği ve geçerliği. Bă̆ımlılık Dergisi, 17(3), 116-122. http://www.ejmanager.com/mnstemps/110/bag_17_03_03.pdf adresinden alınd1

Yurdugül, H. (2005). Ölçek geliştirme çalışmalarında kapsam geçerliği için kapsam geçerlik indekslerinin kullanılması. XIV. Ulusal Eğitim Bilimleri Kongresi. Denizli: Pamukkale Üniversitesi Eğitim Fakültesi. 


\section{Çocuk Katılımı Farkındalık Ölçeği (ÇKFÖ)}

Çocuk Katılımı Farkındalık Ölçeği çocuk hakları bağlamında çocuk katılımı ile ilgili görüşleri belirlemek amacı ile hazırlanmıştır. 18 ifade bulunan ölçeğin cevaplama süresi yaklaşık 6 dakikadır. Sizden istenen, her bir ifadeyi eksiksiz ve görüşünüze uygun olarak tablo üzerinde belirtilen alana $(\mathrm{X})$ işaretlemenizdir. Toplanan veriler bilimsel amaçla kullanılacak ve gizliliği korunacaktır. Samimiyetinizin araştırma açısından oldukça önemli olduğunu hatırlatır, katılımınız için teşekkür ederim.

\begin{tabular}{|c|c|c|c|c|c|c|}
\hline & lım Hakkı İle İlgili Maddeler & 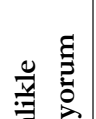 & $\frac{1}{2}$ & $\underset{\mathrm{N}}{\mathrm{N}}$ & 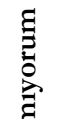 & 吾 \\
\hline 1 & Çocukların görüşleri saygı ile karşılanmalıdır. & & & & & \\
\hline 2 & $\begin{array}{l}\text { Çocuğun etkinliğe başlamadan su içmesi etkinliğin bölünmemesi açısından } \\
\text { gereklidir. Etkinlik esnasında çocuğun su içmesi doğru değildir. }\end{array}$ & & & & & \\
\hline 3 & Öğretmenler çocukların fotoğraflarını kendi sosyal hesaplarında yayınlayabilir. & & & & & \\
\hline 4 & $\begin{array}{l}\text { Yılsonu gösterileri için çocuklar öğretmen tarafından planlanan gösteri planına } \\
\text { uygun olarak hazırlanmalıdır. }\end{array}$ & & & & & \\
\hline 5 & Çocuklara görüşlerini ifade etmeleri için yeterli zaman tanınmalıdır. & & & & & \\
\hline 6 & $\begin{array}{l}\text { Öğretmen ırk ayrımı yapmadan tüm çocuklar için eşit katılım ortamları } \\
\text { yaratmalıdır. }\end{array}$ & & & & & \\
\hline 7 & $\begin{array}{l}\text { Uygulama öğrencileri ödev kapsamında çocuklarla yaptıkları etkinlik } \\
\text { videolarını/fotoğraflarını sınıflarında gösterebilirler }\end{array}$ & & & & & \\
\hline 8 & Sınıf kurallarını öğretmen belirlemelidir. & & & & & \\
\hline 9 & $\begin{array}{l}\text { Öğretmenler çocukların fotoğraflarını ailelerinden izin alarak kendi sosyal } \\
\text { hesaplarında yayınlayabilir. }\end{array}$ & & & & & \\
\hline 10 & Sınıf kuralları uygulama sorumluluğu öğretmende olmalıdır. & & & & & \\
\hline 11 & $\begin{array}{l}\text { Çocukların görüşlerini ifade etmeleri için rencide edilmeyeceklerini bildikleri } \\
\text { güvenilir ortamlar yaratılmalıdır. }\end{array}$ & & & & & \\
\hline 12 & Çocukların fotoğrafları okul internet sitelerinde yayınlanabilir. & & & & & \\
\hline 13 & $\begin{array}{l}\text { Öğretmen cinsiyet ayrımı yapmadan tüm çocuklar için eşit katılım ortamları } \\
\text { yaratmalıdır. }\end{array}$ & & & & & \\
\hline 14 & Çocuklarla yapılan etkinlik örneği videoları okul sitesinde paylaşılabilir. & & & & & \\
\hline 15 & $\begin{array}{l}\text { Çocuklara görüşlerini ifade edebilmeleri için gelişimlerine uygun nitelikli } \\
\text { uyarıcılar sağlanmalıdır. }\end{array}$ & & & & & \\
\hline 16 & Etkinlik esnasında çocuğun tuvalete gitmesine izin verilmemelidir. & & & & & \\
\hline 17 & $\begin{array}{l}\text { Uygulama öğrencileri ödev kapsamında çocuklarla yaptıkları etkinlik } \\
\text { videolarını/fotoğraflarını okuldan bu konuda ailelerin izni olduğuna dair bilgi } \\
\text { aldıktan sonra sınıflarında gösterebilirler. }\end{array}$ & & & & & \\
\hline 18 & Sınıf içinde oturma düzenine öğretmen karar vermelidir. & & & & & \\
\hline
\end{tabular}




\section{Çocuk Katılımı Farkındalık Ölçeği (ÇKFÖ)}

\section{Alt Ölçekler, Puanlama ve Değerlendirme}

Çocuk Katılımı Farkındalık Ölçeği, birinci alt ölçek Katılımda Dekorasyon, çocukların hakkında hiçbir şey bilmeden, izinleri alınmadan ya da bilgilendirilmeden göstermelik izinlerin alındığ1 ya da çocuğu hiçe sayıp sadece aileler ile konuşulan olaylar, etkinlikler veya durumlarda dekor, süs hatta reklam malzemesi olarak kendi ve yaptıkları etkinlik resimlerinin kullanılmasını ifade eder. 6 maddesi $(3,7,9,12,14,17)$ bulunan alt ölçekteki tüm maddeler ters puanlanır ve alt ölçek puanları $(\min =6, \max =30)$ olarak hesaplanır.

İkinci alt ölçek Katulımda Çocuğun Görüşüne Saygı, çocukların görüşlerine her koşulda sayg1lı olmayı ve çocukların görüşlerini ifade edebilecekleri uygun ortam, zaman ve uyarıcı sağlanmasının gerekliliğini ifade eder. 4 maddesi $(1,5,11,15)$ bulunan alt ölçekteki tüm maddeler normal puanlanır ve alt ölçek puanları $(\min =4, \max =20)$ olarak hesaplanır.

Üçüncü alt ölçek Katılımda Zorlama, çocukların bir olay, durum veya konu hakkında herhangi bir bilgiye sahip olmadan sadece söyleneni yapmaları ile ilgilidir. Bu alt ölçek çocukların fikirleri alınmadan sınıf kurallarının, sınıf içi oturacakları yerlerin belirlenmesini ve yapılacak büyük hazırlık süreçleri olan gösterilere sorgusuz katılmalarını ifade eder. 4 maddesi $(4,8,10,18)$ bulunan alt ölçekteki tüm maddeler ters puanlanır ve alt ölçek puanları $(\min =4, \max =20)$ olarak hesaplanır.

Dördüncü alt ölçek Katılımda Ayrım Gözetmeme, çocukların her koşulda hiçbir ayrım gözetilmeden eşit şartlarda katılım firsatlarına erişimi ile ilgilidir. Bu alt ölçek çocukların cinsiyetleri, etnik köken, ırkları göz önüne alınmadan yani ayrım yapılmadan eşit katılım fırsatları yaratılmasını ifade eder. 2 maddesi $(6,13)$ bulunan alt ölçekteki tüm maddeler değişkenler normal puanlanır ve alt ölçek puanları $(\min =2, \max =$ 10) olarak hesaplanır.

Beşinci alt ölçek Katılımda Fizyolojik İhtiyaçlar ise, çocukların fizyolojik ihtiyaçlarının etkinlikleri yarıda bırakması nedeniyle, çocukların ihtiyaç duydukları zaman değil öğretmenin belirlediği zamanlarda giderilmesi ile ilgilidir. Bu alt ölçek çocukların tuvalet ve su içme ihtiyaçlarının etkinliklere ya da öğretmene göre belirlenmesinin doğrudan katılım karşıtı olduğunu ifade eder. 2 maddesi $(2,16)$ bulunan alt ölçekteki tüm maddeler ters puanlanır ve alt ölçek puanları $(\min =2, \max =10)$ olarak hesaplanır.

Çocuk Katılımı Farkındalık Ölçeği normal puanlanmış alt ölçekler (2 ve 4) ve ters puanlanmış alt ölçeklerden (1,3 ve 5) oluşmakta, ters puanlanan maddeler normal puanlanan maddelerin tersine puanlanır. Normal puanlanan alt ölçeklerdeki tüm maddeler "Kesinlikle Katıllyorum” seçeneğinden başlayarak "Kesinlikle Katılmıyorum” seçeneğine doğru 5'ten 1'e doğru puanlanır. Ters puanlanan alt ölçeklerdeki tüm maddeler ise "Kesinlikle Katılmıyorum” seçeneğinden başlayarak "Kesinlikle Katıliyorum" seçeneğine doğru 5’ten 1'e doğru puanlanır. 
Tüm alt ölçeklerde yüksek puanların anlamı çocuk katılımı farkındalığının yüksek seviyede, düşük puanların anlamı ise çocuk katılımı farkındalığın düşük seviyede olduğunu gösterir. 5 alt ölçek ve 18 maddeden oluşan Çocuk Katılımı Farkındalık Ölçeği maksimum puanı $90(18 \times 5)$ puan, minimum puanı ise $18(18 \times 1)$ puandır. Ölçek toplam puanları $\min 18$ ve $\min 18^{\prime}$ e yakın puanların çocuk katılımı konusundaki farkındalığın düşük; $\max 90$ ve $\max 90^{\prime}$ a yakın puanların ise çocuk katılımı konusundaki farkındalı̆̆ın yüksek olduğu şeklinde yorumlanır. Başka bir değişle öğrencilerin ölçek puanlarının düşük olması çocuk katılımı konusunda farkındalığın düşük düzeyde, puanların yüksek olması ise çocuk katılımı konusuna farkındalı̆ı̆n yüksek düzeyde olduğunu gösterir. 